\title{
Centralidade de comércio e serviços na conurbação Cuiabá-Várzea Grande - MT e a precarização do trabalhador
}

\author{
Centrality of trade and services in the Cuiabá-Várzea Grande - MT \\ conurbation and worker precarization
}

\author{
Rosinaldo Barbosa Silva
}

\begin{abstract}
RESUMO
A centralidade comercial e de serviços na Conurbação Cuiabá-Várzea Grande/MT é analisada neste trabalho dentro do processo de crescimento econômico do estado de Mato Grosso. Tal crescimento, acontece dentro do movimento de reestruturação produtiva capitalista, que conduz a produção de centros urbanos como condição necessária para a reprodução do capital. Nesse sentido, os objetivos deste artigo são: realizar revisão conceitual e as relações entre reestruturação produtiva, centros e centralidades urbanas; analisar as taxas de empregos urbanos da Conurbação Cuiabá-Várzea Grande, evidenciar as relações entre a agropecuária e os serviços urbano e explanar sobre a precarização da vida dos trabalhadores que produzem os centros urbanos da Conurbação. A metodologia é constituída de revisão conceitual, de pesquisa secundária, registo fotográfico, produção cartográfica e de entrevista semiestruturada com moradores dos centros urbanos. Aborda-se o crescimento econômico de Mato Grosso e sua relação com a produção de centros urbanos. As principais conclusões desta pesquisa evidenciam a centralidade urbana e econômica como consequência do crescimento da agropecuária, ao mesmo tempo, contraditoriamente, o aumento da taxa de trabalhadores desocupados, a queda do rendimento do trabalhador e a crescente precarização da vida.
\end{abstract}

Palavras-chave: Urbanização; Dinâmica urbana; Reestruturação

\begin{abstract}
The centrality of trade and services in the Cuiabá - Várzea Grande (MT) Conurbation is analyzed within the process of Mato Grosso's economic growth. Such growth happens in the context of capitalist restructuring, with the production of urban centers being key to capital reproduction. In this respect, the purposes of this article are: to provide a conceptual framework and indicate the links between productive restructuring, centers and urban centralities; to analyze the rates of urban employments in the Cuiabá - Várzea Grande Conurbation; to highlight the relations between agribusiness and urban services; and to expand on the precariousness of workers who produce the urban centers of the Conurbation. The methodology consists of conceptual framework, secondary research, photographic record, cartographic production, and semi-structured interview with urban center inhabitants. The economic growth of the state of Mato Grosso is addressed considering its relations with urban center production. On the one hand, the findings associate urban and economic centrality to agribusiness growth, while on the other reveal the rising number of unemployed workers, the drop of average income, the increasing precariousness of life and the loss of social centrality.
\end{abstract}

Keywords: Urbanization; Urban dynamics; Restructuring 


\section{INTRODUÇÃO}

A formação da centralidade política, comercial e de serviços urbanos na Conurbação Cuiabá - Várzea Grande, constitui-se processualmente a partir do crescimento econômico do estadoi de Mato Grosso. Tal crescimento, estabelecido inicialmente no contexto de demarcação territorial e exploração mineral de ouro e diamante, no século XVIII, pelos bandeirantes. Esse processo produziu o centro histórico de Cuiabá e, posteriormente, o de Várzea Grande, após a Guerra do Paraguai (1864 a março de 1870). Com a crise da exploração mineral, houve o aumento da produção agrícola e pecuária, tanto para subsistência, quanto para o abastecimento do mercado regional, de forma que tais atividades estruturaram a economia matogrossense durante mais de um século. A produção da agropecuária fortaleceu-se durante esse longo tempo, tendo sofrido significativo processo de transformação a partir das décadas de 1960/1970, sobretudo com as políticas de integração nacional, que se realizavam através das ações do Estado para efetivar o avanço da fronteira agrícola, rumo à região centro-oeste, através de projetos agropecuários e agroindustriais.

Essas ações contribuíram para o processo de desconcentração industrial e urbana da região Centro-Sul do Brasil, colaborando para que os empresários dessa região, participassem do movimento de internacionalização do capital nas áreas do Bioma Cerrado e da Amazônia. Processo fundamental para o crescimento da produção agropecuária mato-grossense, do fluxo migratório e como consequência, tem-se a formação de aglomerados urbanos, cidades e municípios, sendo significativo, ainda, para a produção de centros urbanos na Conurbação, especialmente a partir de 1970. Assim, a Conurbação se estrutura como centralidade por suas funções administrativas, políticas, financeiras, comerciais e de serviços que se articulam às cadeias produtivas da agropecuária.

Este artigo é fruto de parte de um capítulo da pesquisa de tese e apresenta algumas discussões e resultados. A referida pesquisa possui o seguinte enunciado: o 
processo de reestruturação produtiva capitalista produz centros urbanos como condição necessária para a reprodução do capital, criando novas práticas da centralidade social. Nesse sentido, os objetivos deste artigo são: realizar abordagem conceitual e as relações entre reestruturação produtiva, centros e centralidades urbanas; analisar as taxas de empregos urbanos da Conurbação Cuiabá-Várzea Grande, evidenciar as relações entre a agropecuária e os serviços urbano e explanar sobre a precarização da vida dos trabalhadores, produtores dos centros urbanos.

O artigo está divido em três partes, na primeira são apresentados os procedimentos metodológicos, na segunda são definidos os conceitos de centro e centralidade, onde fundamenta-se ainda as análise, com dados quantitativos oficiais, tal como a Pesquisa Nacional por Amostra de Domicílios Contínua - PNAD Contínua/IBGE. Na terceira parte são analisados os dados empíricos qualitativos concretizados, através de realização de entrevistas com os trabalhadores urbanos, que vive/vivenciaram o processo de avanço da fronteira agrícola. Deste modo, os resultados desta pesquisa, evidenciam a centralidade urbana e econômica como consequência do crescimento da agropecuária, mas há paradoxalmente, o aumento da taxa de trabalhadores desocupados, a queda na renda e a precarização da vida dos trabalhadores.

\section{PROCEDIMENTOS METODOLÓGICOS}

A metodologia é composta por cinco procedimentos. O primeiro trata da abordagem conceitual a respeito da temática; o segundo refere-se à elaboração de mapas cartográficos sobre o crescimento econômico de Mato Grosso; o terceiro é composto pela pesquisa documental e dados secundários; o quarto refere-se à realização de entrevistas semiestruturadas com os moradores da Conurbação; o registro fotográfico é o quinto procedimento.

Para a realização do segundo procedimento, utiliza-se: o software ArcGis e as bases cartográficas, em formato shapefile, disponibilizadas pelo IBGE do ano de 2019. Na confecção dos mapas utiliza-se o Sistema de Referência Geocêntrico para as 
Américas - SIRGAS 2000, sendo que este é o sistema de referência geodésico para o Sistema Geodésico Brasileiro (SGB) e para o Sistema Cartográfico Nacional (SCN), conforme a Resolução No 1/2005 do IBGE. Para elaboração do mapa de localização da Conurbação lança-se mão das bases cartográficas da prefeitura municipal de Várzea Grande e de Cuiabá. Para elaboração dos mapas que representam os dados do estado de Mato Grosso, referentes: à indústria de transformação; ao número de agências bancárias - transações de créditos; de alojamento e alimentação; de armazéns e capacidade de armazenamento, emprega-se os dados do Anuário Estatístico de Mato Grosso, disponibilizado pela Secretaria de Estado de Planejamento de Mato Grosso SEPLAN (2015)ii. Ressalta-se que esses dados são os últimos publicados, ou seja, não foram divulgados informações completas entre anos de 2016 e 2020. De uma gama de informações, selecionou-se apenas as informações de interesse da planilha Excel, posteriormente sistematizadas de acordo com o banco de dados da shapefile, contendo os limites dos municípios de Mato Grosso, para então realizar o procedimento join e gerar os mapas temáticos no software cartográfico.

O terceiro procedimento metodológico constituiu-se de pesquisa documental, no acervo do Arquivo Público de Mato Grosso, durante o mês de outubro de 2017. Levando em conta o recorte temporal de 1910 a 2016, consultou-se diversos jornais de circulação na Conurbação, tais como: A Coligação, A Gazeta, Diário de Cuiabá, Folha do Estado, Folha de Várzea Grande, Folha do CPA, O Estado de Mato Grosso, Correio de Mato Grosso, entre outros. Elucida-se que só foi possível pesquisar os jornais desse significativo intervalo de tempo, porque os acervos não estavam completos, motivo pelo qual consulta-se vários jornais diferentes. O objetivo era investigar as notícias sobre o crescimento econômico de Mato Grosso, bem como as condições sociais dos trabalhadores da Conurbação. Vale ressaltar que, embora esse levantamento tenha contribuído para a pesquisa, ela não correspondeu às expectativas. Também no terceiro procedimento acessa-se os dados secundários, tais como: Censo Agropecuário de Mato Grosso - Séries Históricas (IBGE, 2018) e dados de emprego, renda, 
desemprego da Pesquisa Nacional por Amostra de Domicílios - PNAD Contínua Retrospectiva 2012-2017.

O quarto procedimento efetiva-se através da aplicação de entrevistas semiestruturadas, com transeuntes da área central da Conurbação, durante o mês de janeiro de 2018, especificamente no centro histórico Cuiabá, de Várzea Grande e no centro comercial do Bairro Cristo Rei (onde se localiza a Br Foods). Pretendia-se realizar as entrevistas nas casas dos moradores, mas encontrou-se dificuldades, principalmente no Centro de Cuiabá e Várzea Grande, onde muitos negavam ceder tempo e atenção. No centro do Cristo Rei, teve-se mais receptividade, por isso, a maior parte das entrevistas com os moradores se deu nessa localidade. No total, foram realizadas 30 entrevistas com média de $25 \mathrm{~min}$ de duração, transcritas nos meses de fevereiro e março de 2018. Elas compõem os principais dados qualitativos desta investigação, a partir dos quais pretende-se compreender como os moradores se relacionam com o centro urbano e como ocorrem as mudanças sociais na produção da centralidade.

O quinto procedimento trata-se do registo fotográfico, tanto na Casa de Artes de Várzea Grande, quanto em outros pontos da Conurbação. Todas essas fases contribuíram para a compreensão da dinâmica da produção de centralidades e precarização do trabalhador.

É essencial destacar que a área de estudo é a Conurbação Cuiabá-Várzea Grande. Todavia, diversos problemas de acesso e disponibilidade de dados especificamente da Conurbação, durante o decorrer da pesquisa, impossibilitou a confluência de informações para a análise da Conurbação como um todo. Alguns dados oficiais não constam informações de Várzea Grande, outros apresentam da região metropolitana, sendo impossível desagregar dados apenas da Conurbação.

Para exemplificar, na tabela 1 “População Ocupada-Setores - Mato Grosso, Região Metropolitana e Cuiabá 2012-2018 (mil)", percebe-se que não há dados apenas de Várzea Grande desagregado. Porém, as informações dessa cidade estão agregados dentro da região metropolitana. Tal problema é um fato, considerando a inexistência 
de gestão compartilhada entre os gestores das duas cidades e, consequentemente, da produção de dados da área conurbada. Quando possível, agrega-se os dados das duas cidades para realizar a análise da área de pesquisa em sua totalidade, contudo, em alguns momentos isso não foi possível, inclusive na realização das entrevistas semiestruturadas com os moradores. Por isso, pode-se perceber, uma explanação ora mais focada na Conurbação, ora em uma das cidades, porém, sem comprometer as diversas possibilidades de análise aqui realizadas.

\section{A PRODUÇÃO DE CENTROS URBANOS NA CONURBAÇÃO CUIABÁ-VÁRZEA GRANDE E A PRECARIZAÇÃO DO TRABALHADOR}

De modo geral, este trabalho busca criar relações entre o crescimento econômico de Mato Grosso, em especial da agropecuária, com a produção de centros urbanos e de como esse processo produz a perda da centralidade social. O crescimento econômico é aqui analisado, dentro do movimento de reestruturação capitalista. Este pode ser definido como processo de "reprodução das relações sociais de produção" (LEFEBVRE, 1973, p. 97), revelado nos movimentos de desajustes da própria produção e de formação de crises econômicas no interior do ciclo do capital. Processo que abarca a reprodução dos meios de produção no âmbito da fábrica (mudanças tecnológicas, organização do trabalho, máquinas, insumos e matérias-primas) e a reprodução das relações sociais, ou seja, do trabalhador e da sociedade como um todo, envolvendo todas as esferas da vida social, através do consumo de mercadorias, alimentando o ciclo produtivo: produção-circulação-troca-consumo.

A reestruturação produtiva, desse modo, é compreendida na totalidade da sociedade capitalista, que se desenvolve na lógica da produção e do consumo. Estes últimos possibilitam a rotação do ciclo do capital, processo que produz transformações no campo e na cidade. Não obstante, perpetuam-se as relações de classe sociais em oposição, o monopólio dos meios de produção, a propriedade privada da terra, o capital, o trabalho alienado, a dominação econômica, política e a dependência das ações do Estado, em suma, tudo o que é estruturante da sociedade capitalista, ainda 
que se trate de processo de criação de novas mercadorias, novos estilos de vida, novas práticas sociais, em outras palavras, novas relações sociais de produção. O artifício de reestruturação produtiva necessita criar bases para a reprodução do capital e, a cidade, sobretudo os centros urbanos, permite esse processo. Sendo assim, o centro urbano tem uma característica fundamental no crescimento da sociedade capitalista, pois: “condensa riquezas, meios de ações, conhecimentos informações, a "cultura”. Tudo. A essas capacidades e poderes, ele superpõe o poder supremo, a concentração dos poderes: a Decisão. O sistema decisional se diz (abusivamente) racional" (LEFEBVRE, 2000, p. 696).

A possibilidade do centro de concentração da riqueza social, do poder político e econômico, bem como dos meios de produção, faz que o centro urbano seja um meio de reprodução do capital. Segundo Lefebvre (2000), centro remete à ideia de concentração, junção, reunião de algo, e também à ideia de centro da cidade, lugar de concentração de coisas, objetos e de pessoas. Sendo assim, definimos centro urbano como o lugar de concentração socioespacial de capitais fixos produzidos socialmente, isto é, lugar de concentração de tudo aquilo que engloba a força produtiva e está em movimento no processo de produção (valor em movimento), tal como os portos, os aeroportos, as instituições financeiras (os Bancos), as instituições Estatais, os estabelecimentos comerciais, industriais e de serviços. A possibilidade de que o centro concentre riqueza social, o poder político e econômico, bem como os meios de produção, faz com que ele e a cidade, sejam condição, meio e produto da reprodução do capital, tal como afirma Carlos (2011).

Nesse sentido, todo centro revela a centralidade, ao mesmo tempo em que a centralidade se expressa pela concentração que a estrutura. Mas o centro se revela pela localização, e a centralidade, pelo movimento social que a constitui - nisso, incluem-se os fluxos de pessoas, mercadorias e de informações (SPOSITO, 2013). Com efeito, para Lefebvre (2000), a centralidade significa a apropriação plena do centro pelo uso social, marcado pelo encontro, solidariedade e sociabilidade. Isso implica considerar que, na cidade, há vida urbana como um todo, sendo possível que a 
centralidade se desenvolva em qualquer lugar dela. No entanto, o desenvolvimento de uma centralidade urbana (econômica e social) se dá principalmente através dos interesses de classes, do Estado e dos setores privados. Estes podem produzir uma área central onde se instalam instituições, infraestruturas, aglomerados industriais, residenciais, de comércio e serviços, com finalidade de dinamizar a economia local. Assim, é preciso levar em consideração a produção de centros urbano, tendo o Estado como agente regulador e ordenador, as suas estreitas relações com os setores privados, na busca pela reprodução do capital, ocasiona a perda da centralidade social e redução da qualidade de vida do trabalhador.

A partir da definição de reestruturação produtiva, centro e centralidade, situamos brevemente a relação entre o crescimento econômico de Mato Grosso e a qualidade da produção de centros urbanos.

A Conurbação Cuiabá-Várzea Grande, figura 1, possui 897.518 habitantes ${ }^{i i i}$ (IBGE, 2019). Nela a produção de centros e centralidades se realiza a partir do crescimento econômico do estado de Mato Grosso, estabelecida inicialmente no contexto de demarcação territorial e exploração mineral de ouro e diamante, no século XVIII, pelos bandeirantes. Esse processo produziu o centro histórico de Cuiabá e, posteriormente, o de Várzea Grande, após a Guerra do Paraguai (1864 a março de 1870). Com a crise da exploração mineral, houve o aumento da produção agrícola e pecuária, tanto para subsistência, quanto para o abastecimento do mercado regional, de forma que tais atividades estruturaram a economia mato-grossense durante mais de um século. A produção da agropecuária fortaleceu-se durante esse longo tempo, tendo sofrido significativo processo de transformação a partir das décadas de 1960/1970, com as políticas de integração nacional realizadas por meio das políticas do Estado para efetivar o avanço da fronteira agrícola rumo à região centro-oeste, com projetos agropecuários e agroindustriais. 
Figura 1. Mapa de localização da Conurbação Cuiabá-Várzea Grande MT, 2020

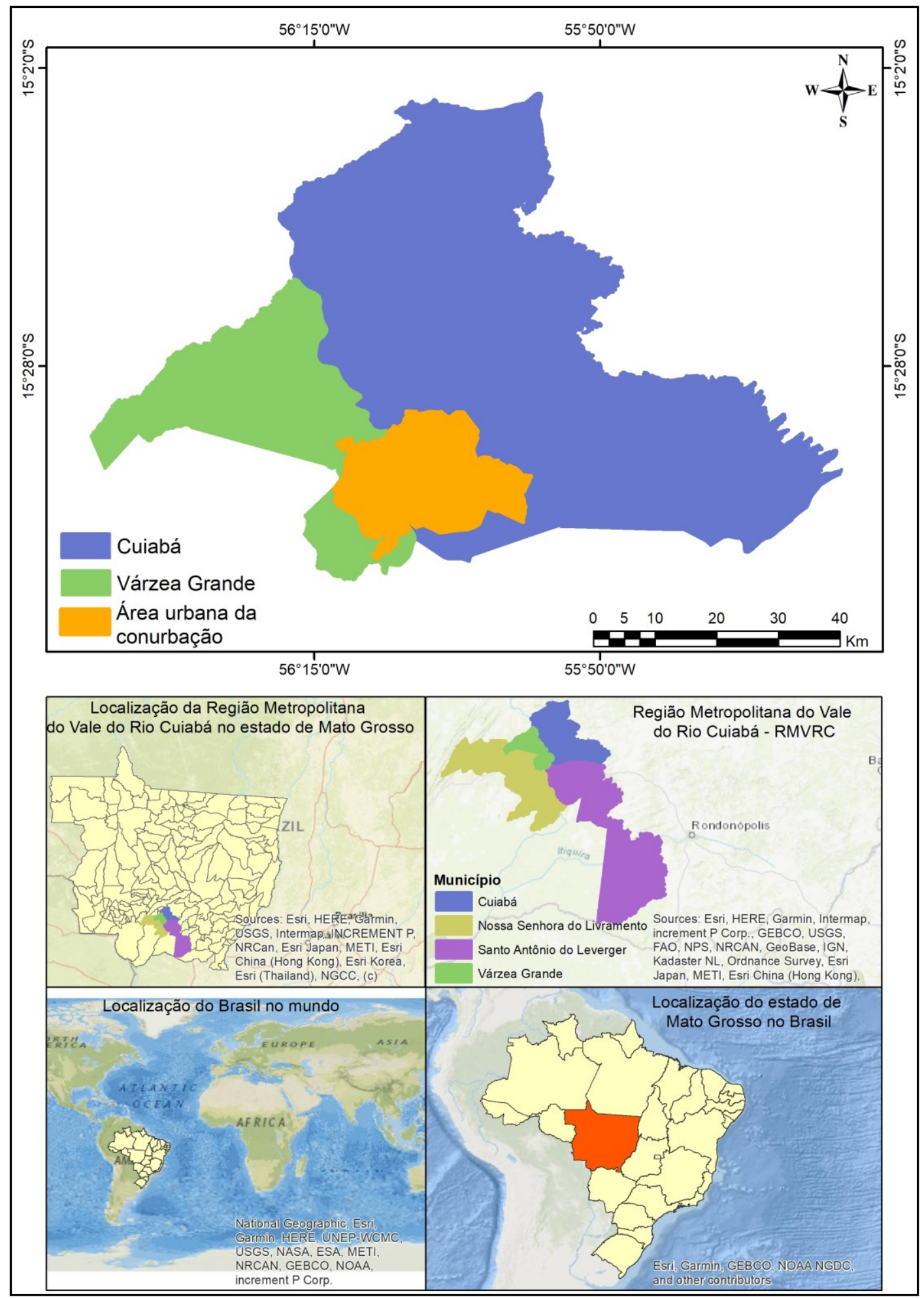

Fonte: Elaborado pelo autor, 2020.

Tais ações contribuíram para o processo de desconcentração industrial e urbana da região Centro-Sul do Brasil, colaborou para que os empresários dessa região participassem do movimento de internacionalização do capital nas áreas do Bioma Cerrado e da Amazônia, fundamental para o crescimento da produção agropecuária 
mato-grossense, o aumento do fluxo migratório, a criação de municípios ${ }^{i v}$, de cidades e de formação de aglomerados urbanos, sendo significativo, ainda, para a produção de centros urbanos na Conurbação, especialmente a partir de 1970. Gradativamente, a Conurbação deixou de responder às relações sociais da produção mineral, que produziu os centros históricos com suas ruas estreitas e casarões coloniais, para atender às novas necessidades advindas da produção da agropecuária.

Figura 2: Taxas Médias Anuais de Crescimento - Brasil, Centro-Oeste e Mato Grosso 1985-2003 (\%).

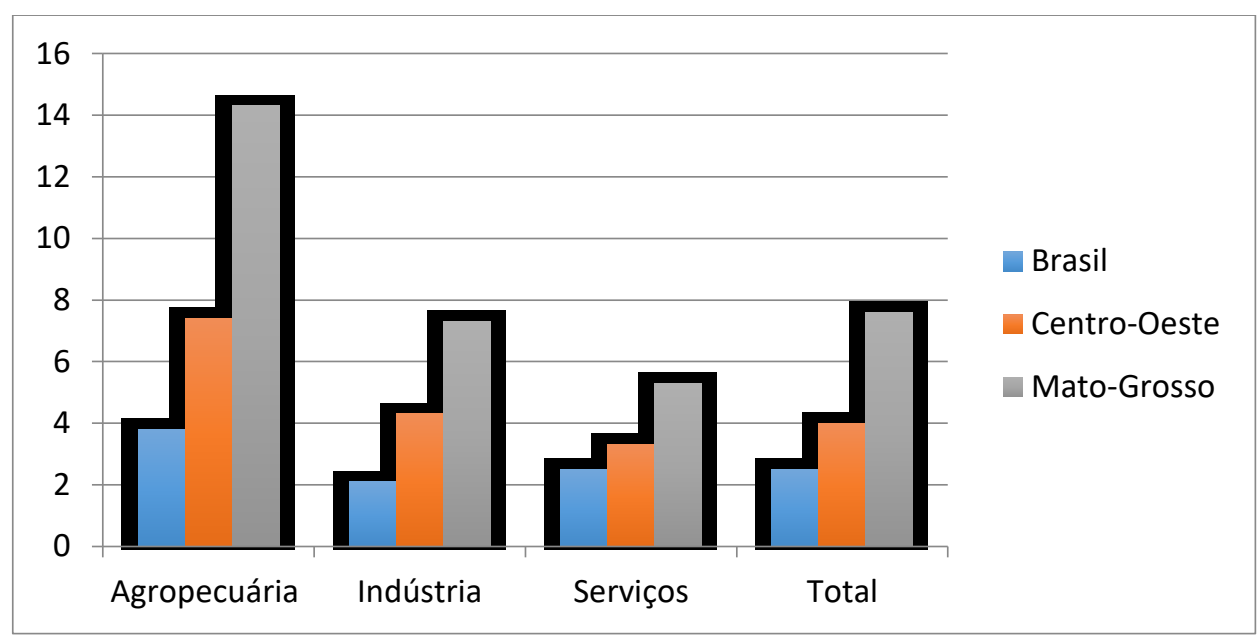

FONTE: IBGE - Contas Regionais / Plano MT + 20 - MATO GROSSO, 2011. Organizado pelo autor, 2020

Com a redefinição da base produtiva, novos investimentos se concretizam no estado de Mato Grosso, que desponta como parque agroindustrial no cenário nacional. Esse processo que gera trabalhos no campo (embora em menor número, dado à mecanização da produção) e na cidade, inter-relacionando as atividade da agropecuária, indústria, comércio e serviços. A estruturação produtiva do estado de Mato Grosso, com grande representatividade nacional, surge nos índices de crescimento anual de 1985 a 2003, tal como ilustrado na figura 2. O setor da agropecuária possui o maior índice de crescimento anual, com 14,3\%, seguido pela indústria, com 7,3\%, e serviços, com 5,3\%. Esses dados revelam uma visível vantagem econômica de Mato Grosso em comparação ao crescimento econômico anual do Brasil e da região centro-oeste, no mesmo intervalo de tempo. 
Os dados econômicos mais recentes foram publicados em $2019^{\vee}$ pela Secretaria de Planejamento de Mato Grosso - SEPLAN, onde constata-se que as taxas médias anuais de crescimento por setor econômico do estado de Mato Grosso são as seguintes: agropecuária 13,9; indústria 13,7 e serviços 15,1, entre os anos de 2002 e 2016.

Os números históricos do crescimento dos setores econômicos do estado de Mato Grosso contribuem para a compreensão da dinâmica social e das cidades, estreitamente ligadas à produção-circulação-troca e consumo, no processo de avanço produtivo capitalista. Nesse arranjo, a Conurbação se estrutura pela concentração do poder político, econômico, administrativo, prestação de serviços terciários e produção industrial. Ela "representa economicamente o suporte às atividades agroindustriais no estado" (CHILLETO 2015, p. 18,19). Essa estrutura urbana proporciona o apoio logístico e estratégico. Isso constitui a especializações das funções urbanas e a complexidade dos equipamentos oferecidos à sociedade nas áreas de saúde, indústria de transformação, alojamento e alimentação, número de agências bancárias, operações financeiras, armazéns, entre outros. Conforme a Secretaria de Estado de Desenvolvimento Econômico, o Distrito Industrial de Cuiabá possui cerca de 251 empresas diversas, gerando cerca de 4.746 empregos diretos nos mais variados setores, tais como:

Armazenamento de cereais; beneficiamento de borracha/indústria de artefatos de borracha; beneficiamento de cereais, produtos alimentícios/produtos animais; beneficiamento de madeira/fabricação de móveis, forro/depósito de madeira; beneficiamento, distribuição e comércio de derivados de petróleo; comércio varejista e atacadista; construção civil/artefatos de concreto/produtos cerâmicos; indústria e comércio, equipamentos rodoviários e serviços mecânicos em geral/vaporização; indústria química e gases; indústria, comércio de produtos metalúrgicos; transporte de cargas/transporte coletivo; indústria da confecção; indústria de fertilizantes; prestação de serviços (SEDEC, 2019). 
Garbeline (2014) constatou o crescimento do Distrito Industrial de Cuiabá ao longo do tempo, e identificou os segmentos de indústria que se instalaram a partir de 2010, quais sejam: armazenamento de cereais; beneficiamento de cereais, produtos alimentícios, produtos animais; construção civil, artefato de concreto e produtos cerâmicos; comércio varejista e atacadista; beneficiamento distribuição e comércio de derivados de petróleo e indústria química e gases. Destacamos, ainda, algumas indústrias instaladas no Distrito, tais como: Cargill Alimentos Ltda. (CDMT); Bravo Serviços Logísticos Ltda; Grupal Agroindustrial; Luft Agribusiness - Cuiabá (Sementes); Rico Nutrição Animal Ltda; IF Distribuidora de Alimentos LTDA; Bimetal Indústria e Metalúrgica; Bio Óleo Indústria e Comércio de Biocombustível, entre outros.

A complexidade da teia da produção do agronegócio se vincula às grandes empresas mundiais que controlam o mercado, tal como explica Muller (1989): “O comércio mundial de oleaginosas é dominado por pequeno número de grandes empresas como: Cargill Inc., Continental Grai Co., Cock Industries, Louis Dreyfus Co. Elas geralmente abarcam todas as esferas produtivas". No segmento de empresas de genética avícolas para carnes, temos a Peterson (EUA), que possui parcerias nacionais representadas pela Globo Aves que, no Distrito Industrial, atua como Globoaves Agro Avícola. Além disso, nesse ramo ainda destaca-se a Cobb (EUA) e Shaver, empresa canadense que tem a Avipal como parceira nacional, que, por sua vez, foi comprada pela Perdigão em 2008. Assim, tanto a Cobb quanto a Shaver contam com a parceria da Brfoods, que possui planta industrial em Várzea Grandevi.

A Monsanto, que é uma das maiores companhias controladoras de sementes no mundo, possui filial na Avenida Historiador Rubens de Mendonça - CPA e inaugurou em 2007 o centro de distribuição de sementes em Cuiabávii para melhorar a logística de atendimento dos produtores mato-grossenses. Além da Monsanto, encontra-se localizada no Distrito Industrial de Cuiabá a Cargill Alimentos Ltda. e, na Rodovia dos Imigrantes, o Grupo Matsuda. Este último foca no agronegócio, nas facetas da produção e comercialização de sementes para pastagens, suplementos minerais, rações para peixes, equipamentos agrícolas e saúde animal. A Monsanto, Cargill e 
Matsuda se colocam como os maiores produtores e comerciantes da Conurbação nesse ramo.

As empresas que dominam o comércio de tratores e colheitadeiras também estão presentes na Conurbação, são elas: Valtra Valmet; John Deere; New Holland e Case IH. A Case IH, por exemplo, inaugurou em Cuiabá um Centro de Distribuição de mais de 11 mil peças de equipamentos agrícolas para atender a demanda em Mato Grosso. Além disso, outras empresas, como a VGrande e a Dimaq, localizadas em Várzea Grande e em Cuiabá, respectivamente, comercializam tratores e colheitadeiras destas e de outras marcas. Uma das principais empresas de equipamentos e implementos agrícolas no Brasil é a Agrale, no segmento tratores leves, cujos produtos são comercializados através da empresa Macro Peças, localizada na Avenida Mário Andreaza em Várzea Grande. No segmento arado, grade e subsolador, no cenário nacional, destaca-se a Marchezan, que conta com a Marchesan Implementos e Máquinas Agrícolas em Cuiabá para venda de seus produtos.

No segmento de distribuição de calcário e adubos, localizam-se, na Conurbação, diversas empresas, tais como: Agro Amazônia Produtos Agropecuários, situada na Av. Tenente Coronel Duarte; Pecuagro Matsuda Sementes, na Av. Beira Rio; Sementes Lavroquimica, no Distrito Industrial; Araguaia Produtos Agropecuários, na Av. Miguel Sutil; Agropev Produtos Agropecuários, na Av. Couto Magalhães, entre outras. Nelas, é possível encontrar produtos das principais empresas agrícolas do Brasil, como, por exemplo, da Ipacol, Jumki, Sata, Piccin, Vicom, Baldan, Jam, Marchesan (MULLER, 1989, 195). Já no ramo de indústria veterinária, uma das líderes no País é a Tortuga, que possui uma filial na Avenida Beira Rio, em Cuiabá. Na área de comercialização de agrotóxico, por sua vez, encontram-se diversas empresas na Conurbação, dentre elas: a Home Compost e a Damaforte Produtos Agropecuários, ambas localizadas na Av. Fernando Corrêa da Costa; a Agro Amazônia Produtos Agropecuários, na Av. Tenente Coronel Duarte; a Vetquímica Comercial Agrícola Ltda., localizada na Rod. Palmiro Paes de Barros; a Agrogenes, na Av. Beira Rio (marca Syngenta e Gianni). Nesses estabelecimentos, é possível encontrar produtos das empresas que mais faturam no 
Brasil no ramo de comercialização de agrotóxico, tais como Bayer, Novartis (antiga CibaGeigy e Sandoz), Dow Química, Shell, dentre outros.

A importância da Conurbação para os negócios agrícolas contribuiu para que o Grupo Bom Futuro, uma das maiores empresas de agronegócio do Brasil, mudasse a sua sede administrativa para Cuiabá em 2014. Localizada na Av. dos Florais, a empresa atua no segmento agronegócio, subdividindo-se nos segmentos: agrícola; pecuária; piscicultura; sementes; armazenagem e transportes, tendo iniciado atuação também no ramo imobiliário a partir de 2013. Os quatro sócios do grupo são: Eraí Maggi Scheffer, Elusmar Maggi Scheffer, Fernando Maggi Scheffer e José Maria Bortoli. Essas configurações espaciais, sobretudo da área agroindustrial, de serviços e de comercialização dos produtos agropecuários, potencializam a centralidade econômica da Conurbação.

A produção e o armazenamento dos produtos agrícolas revelam-se distribuídas desigualmente no estado de Mato Grosso. Constata-se na figura 3, o número de armazéns e a capacidade armazenamento da produção agrícola total, ou seja englobase sistema o convencional e o graneleiro. Os maiores números de armazéns para estocagem da produção agrícola, estão distribuídos nos municípios ao centro-norte do estado, tais como: Sorriso, 213; Nova Mutum, 92; Lucas do Rio Verde, 86 e Sinop com 53 armazéns. Ao oeste do estado, destacam-se os municípios de Campo Novo do Parecis com 115 armazéns e Sapezal com 112, enquanto que ao Sudeste sobressaemse Primavera do Leste com 147 e Rondonópolis com 84. A Conurbação não é produtora de grãos, mas ainda assim verifica-se a contribuição de Cuiabá com 11 armazéns e de Várzea Grande com 19 armazéns, juntas, possuem capacidade de armazenamento de 395.282 toneladas da produção agrícolaviii. No que se refere a capacidade de armazenamento é evidente o destaque do município de Sorriso com mais de 3,7 milhões de toneladas, seguidos de: Primavera do Leste com 2,2; Sapezal, 1,6 e Sinop 1,5 milhões de toneladas, respectivamente. 
Figura 3. Mapa do número Armazéns e Capacidade de Armazenamento (total, convencional e graneleiro) em Mato Grosso, 2014

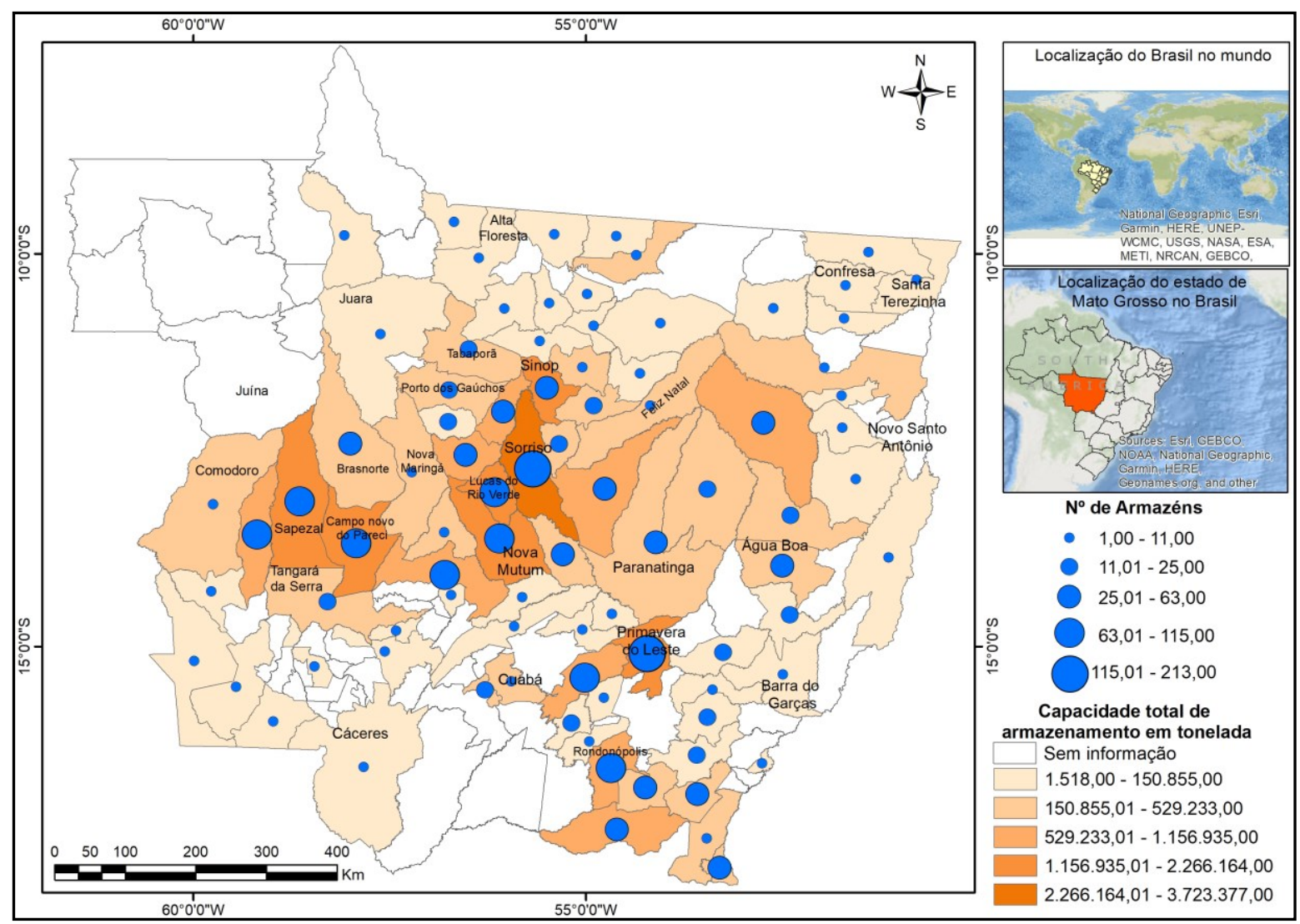

Fonte: Elaborado pelo autor, 2020

A indústria de transformação compreende diversas atividades que realizam transformações físicas, químicas ou biológicas de materiais, a fim de criar novos produtos a partir da exploração da matéria-prima. As atividades industriais como: fabricação de produtos alimentícios; bebidas; produtos têxteis; vestuário; acessórios; móveis; produtos químicos; massas para concretos; máquinas; equipamentos diversos; bem como manutenção e reparação de máquinas, concentram-se na Conurbação (figura 4). O número total de indústrias de transformação no estado Mato Grosso é de 3.147, sendo que Cuiabá possui 596 e Várzea Grande, 272, totalizando 868, ou seja, 27\% das indústrias de transformação do estado. Além disso, a Conurbação centraliza as empresas de transporte, armazenagem e correio, sendo que Várzea Grande possui 182, e Cuiabá, 394 , totalizando 576 empresas nesses ramos, $26 \%$ do total de 2.214 , distribuídas nos demais municípios do estado. 
Figura 4. Mapa - número de Indústria de Transformação e de Empresas de Transporte, Armazenagem e Correio em Mato Grosso, 2014

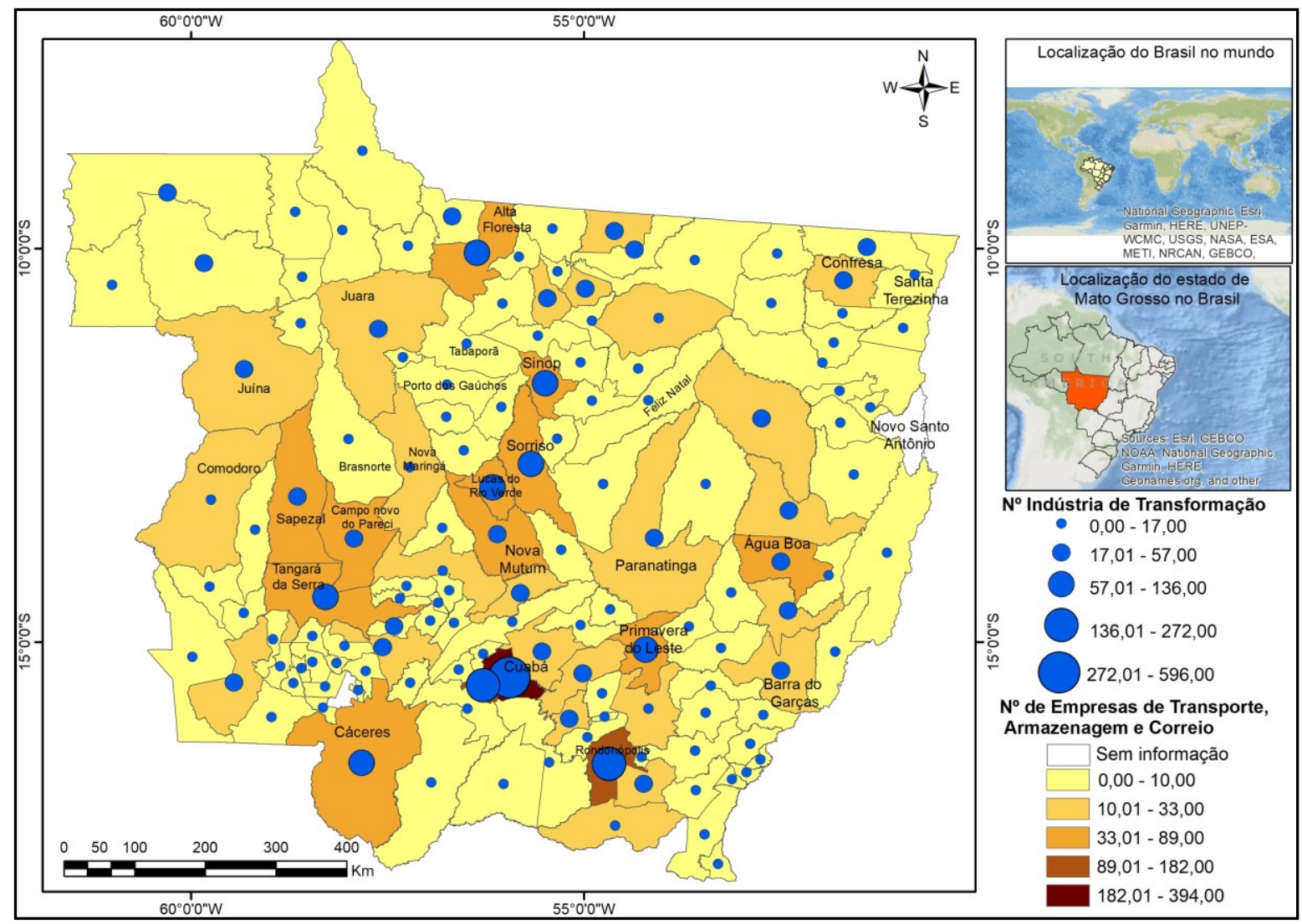

Fonte: Elaborado pelo autor, 2020.

Verifica-se na figura 5, que a quantidade de empresas de alojamento e alimentação estado é de 4.064 , sendo que 29,25\% delas concentram-se na Conurbação (1.189), em Várzea Grande são 241 e, em Cuiabá, 948. Esses números mostram a significativa variedade de hotéis, bares e restaurantes existentes que prestam serviços à comunidade local e aos diversos turistas, inclusive os "turistas de negócios". No estado, a quantidade de prédios voltados à arte, cultura, esporte e recreação é apenas 269, sendo que a Conurbação concentra 113 desses estabelecimentos, o que representa $42 \%$ do total. Além disso, a Conurbação reúne maior oferta de serviços na área de saúde humana, serviços sociais, informação, comunicação, estabelecimento educacionais, construção civil, atividades imobiliárias, entre outros. Esses dados revelam a distribuição profundamente desigual dos bens financeiros, do acesso aos equipamentos sociais, culturais e de lazer. Priva-se a maior parte da população o direito 
à vida digna e aos direitos sociais de modo amplo, situação que demonstra a dominação política e econômica que estruturam as práticas sociais, as relações de reprodução da força de trabalho e de reprodução da vida situadas cada vez mais em níveis de precariedade.

Figura 5. Mapa - número de empresas de alojamento, alimentação, estabelecimentos de artes, cultura, esporte e recreação em Mato Grosso, 2014

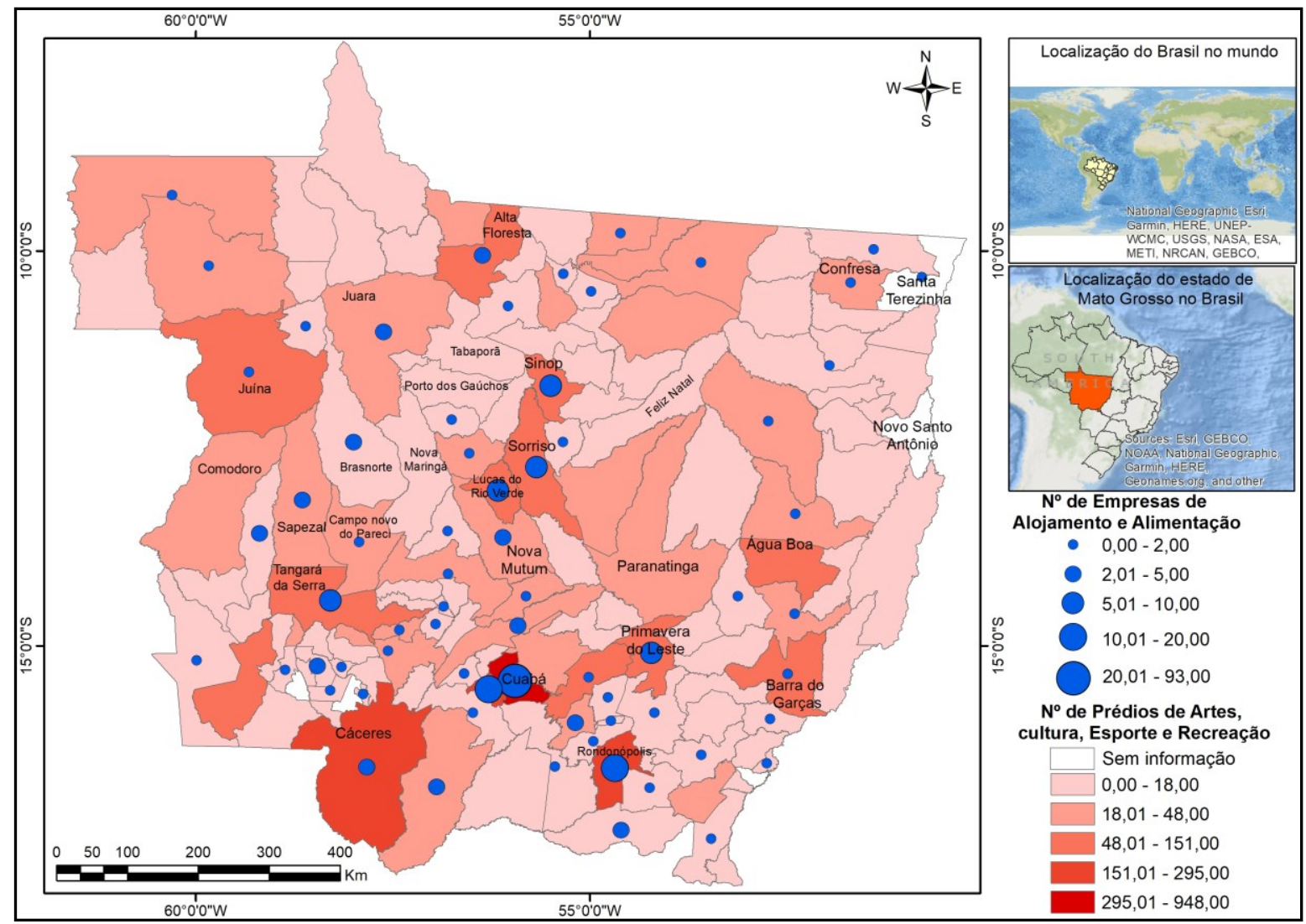

Fonte: Elaborado pelo autor, 2020.

A centralidade econômica da Conurbação é identificada, sobretudo, pelo número de agências bancárias que possibilitam diversas operações creditícias (figura 6). As operações de créditos no estado de Mato Grosso em 2014 foram mais de R\$ 35 trilhões, mais de $\mathrm{R} \$ 13$ bilhões concentradas na Conurbação (37,14\% do total). Em Várzea Grande foram movimentados cerca de R\$1.2 bilhão, montante bem menor do que circulado em Cuiabá (R\$ 12 bilhões). Para fins de comparação, a cidade de Sorriso, a maior produtora de grãos no estado, movimentou no mesmo ano pouco mais de $\mathrm{R} \$$ 
1.3 bilhão de reais. Tal análise é fundamental para relacionar a concentração das movimentações financeiras na Conurbação, apesar da produção do agronegócio concentrar-se em diversos municípios do estado. O poder público estadual e os empresariados buscam fortalecer a Conurbação como um centro financeiro altamente dinâmico e moderno, para especializá-la ainda mais e impulsionar o crescimento da agropecuária modernaix.

Figura 6. Mapa - número de Operações de Crédito e Agências Bancárias em Mato Grosso, 2014

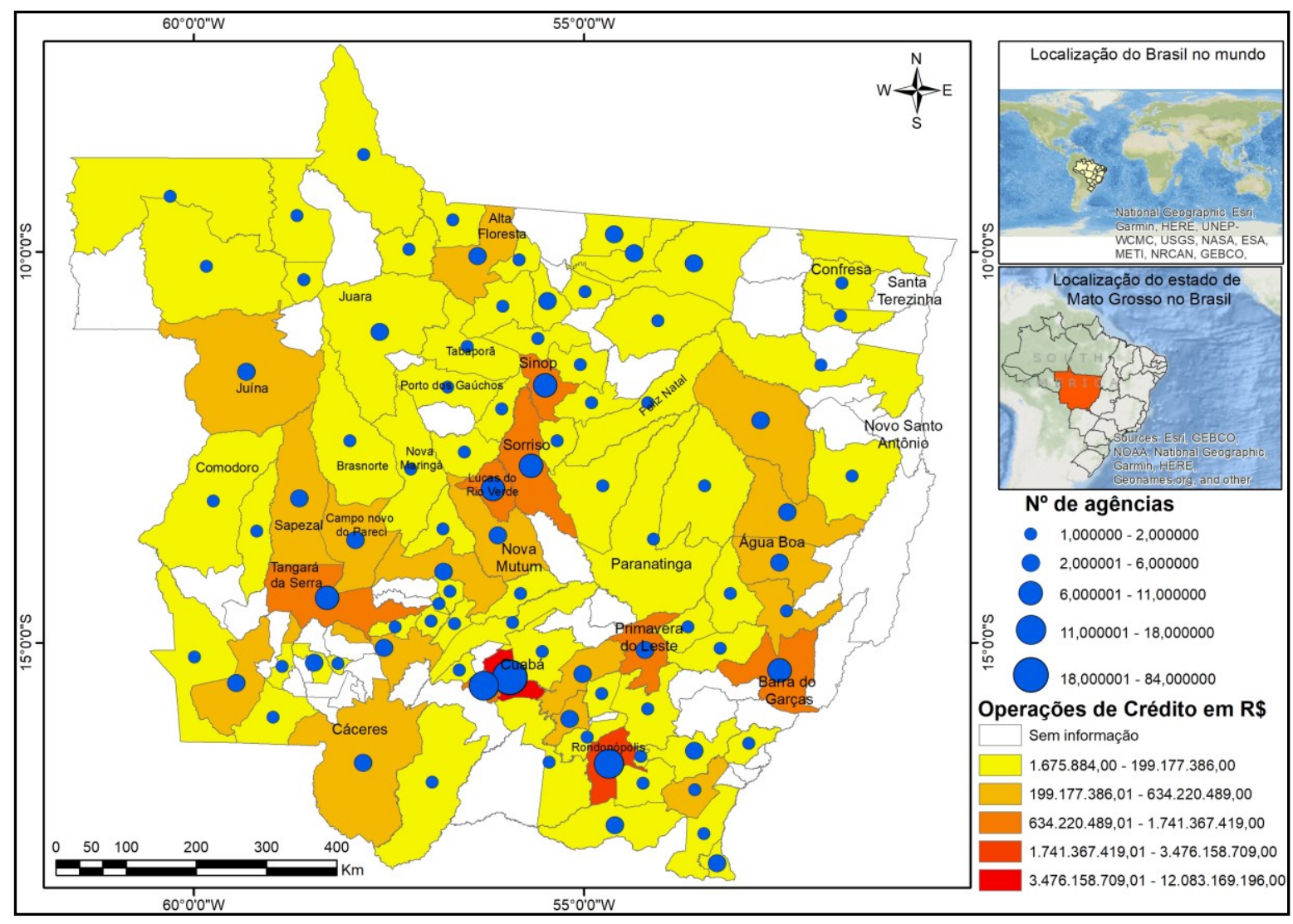

Fonte: Elaborado pelo autor, 2020.

O crescimento econômico de Mato Grosso, em especial da agropecuária, influenciou diretamente o crescimento da indústria e das atividades de serviços. No estado, o número de trabalhadores empregados no setor público é significativo (figura 7): em 2012, eram 186,7 mil pessoas, chegando a 189,2 mil em 2014. Em 2015, houve queda significativa para 181 mil, entretanto, em 2006 os índices voltaram a subir para 
189 mil, ultrapassando a taxa de 2012. Na Região Metropolitana (inclui-se a Conurbação), a oscilação no número de trabalhadores ocupados no setor público é maior. Houve crescimento de 2012 para 2013, de 63,5 para 65,5 mil pessoas. Porém, de 2014 a 2016 os índices acumularam queda de 62 mil para 59,5 mil pessoas, ou seja, abaixo da taxa de 2012.

Figura 7. Número de pessoas empregadas no setor público - Mato Grosso e Região Metropolitana

RMVR

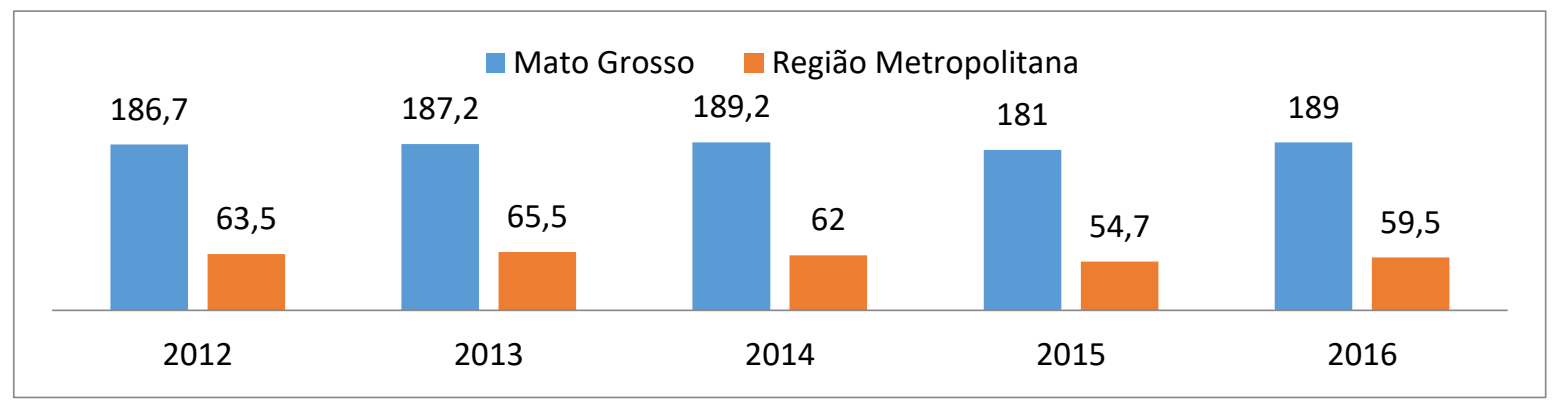

Fonte: PNAD Contínua - Retrospectiva 2012-2017 - Médias Anuais - www.ibge.com.br, acesso: agosto de 2018. Organizado pelo autor.

A porcentagem de trabalhadores com carteira de trabalho assinada entre os empregados do setor privado é alta de 2012 a 2017, conforme a figura 8. Contudo, na Região Metropolitana, a oscilação é significativa, como se pode ver pela queda nas taxas de 2012 para 2013 e de 2015 para 2016.

Figura 8. Empregados com carteira entre os empregados do setor privado (\%)

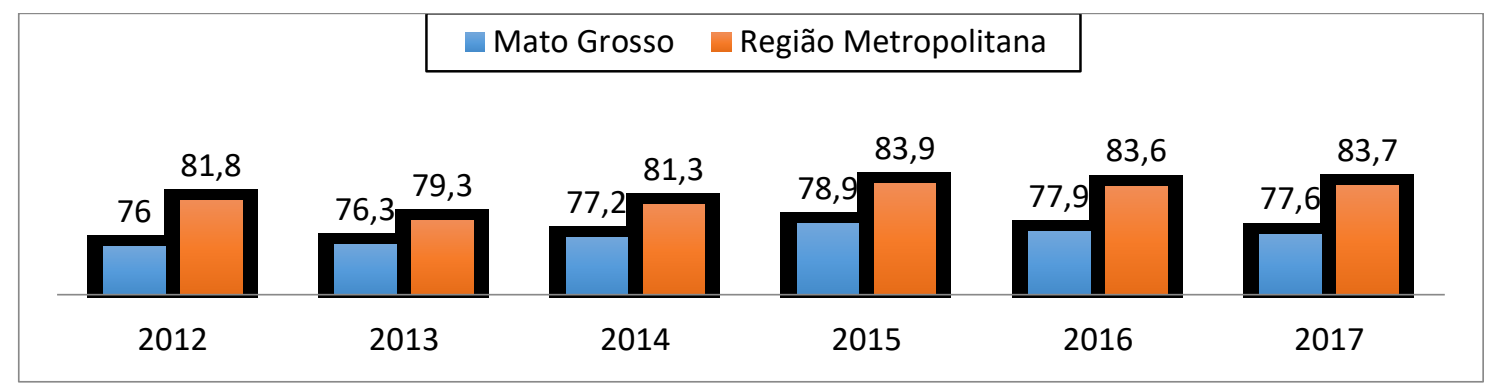

Fonte: PNAD Contínua - Retrospectiva 2012-2017 - Médias Anuais - www.ibge.com.br, acesso: agosto de 2018. Organizado pelo autor. 
Constata-se o quantitativo de trabalhadores ocupados por segmento de setores econômicos entre o ano de 2012 e 2017 na tabela 1. Com relação à população ocupada em Mato Grosso, verifica-se que houve aumento de um milhão, quatrocentos e sessenta e quatro mil em 2012 para pouco mais de um milhão e meio de pessoas em 2017. Desse total, uma parcela significativa de pessoas ocupadas concentra-se na Região Metropolitana de Cuiabá (27,58\%) e na cidade de Cuiabá (18,37\%), conforme a média acumuladax. Entretanto, o percentual de pessoas desocupadas na Região Metropolitana e na cidade de Cuiabá é também mais elevado, 32,42\% e 22,63\%, respectivamente. De qualquer maneira, destacamos que os índices de trabalhadores desempregados entre 2012 e 2017 são crescentes, tanto em Mato Grosso quanto na Região Metropolitana e em Cuiabá, o que implica considerarmos a dissociação entre o significativo crescimento da agropecuária e a geração de emprego e renda, analisada no primeiro capítulo da tese $\mathrm{x}^{\mathrm{xi}}$.

No setor da agropecuária, podemos constatar a oscilação do número de pessoas empregadas em Mato Grosso de 2012 a 2017, que variam de 238,7 a 253,7 mil trabalhadores. Entretanto, a participação de pessoas empregadas nesse setor econômico na Região Metropolitana é irrisória: 4,40\% e apenas 2,00% em Cuiabá. Isso significa que a produção em si não está em Cuiabá ou na Região Metropolitana, visto que 94,60 \% dos trabalhadores da agropecuária estão distribuídos nos municípios do interior de Mato Grosso.

Tabela 1: População Ocupada-Setores - Mato Grosso, Região Metropolitana e Cuiabá 2012-2018 (mil)

\begin{tabular}{|c|c|c|c|c|c|c|c|c|}
\hline $\begin{array}{l}\text { SETORES } \\
\text { ATIVIDADES }\end{array}$ & RECORTE & 2012 & 2013 & 2014 & 2015 & 2016 & 2017 & $\%$ \\
\hline \multirow{3}{*}{ Pop. ocupada } & Mato Grosso & 1464 & 1527 & 1560,2 & 1526,5 & 1499,7 & 1521,5 & \\
\hline & $\begin{array}{l}\text { Região } \\
\text { Metropolitana }\end{array}$ & 419 & 428,2 & 422,7 & 418,5 & 406 & 415,2 & $27,58 \%$ \\
\hline & Cuiabá & 283 & 289,5 & 279,5 & 274,7 & 272 & 273,2 & $18,37 \%$ \\
\hline \multirow{3}{*}{ Pop. desocupada } & Mato Grosso & 85,2 & 71 & 65 & 97,7 & 154,2 & 149,5 & \\
\hline & $\begin{array}{l}\text { Região } \\
\text { Metropolitana }\end{array}$ & 25 & 23,7 & 22,7 & 34,5 & 50,7 & 45,5 & $32,42 \%$ \\
\hline & Cuiabá & 17 & 15 & 15 & 21,7 & 36,2 & 35,7 & $22,63 \%$ \\
\hline
\end{tabular}




\begin{tabular}{|c|c|c|c|c|c|c|c|c|}
\hline AGROPECUÁRIA & & & & & & & & \\
\hline Agricultura, & Mato Grosso & 247 & 254,2 & 253,7 & 247,2 & 248,5 & 238,7 & \\
\hline $\begin{array}{l}\text { pecuária, florestal, } \\
\text { pesca }\end{array}$ & $\begin{array}{l}\text { Região } \\
\text { Metropolitana }\end{array}$ & 12 & 9 & 11,7 & 11,7 & 15,2 & 11 & $4,40 \%$ \\
\hline aquicultura & Cuiabá & 5,2 & 4 & 5 & 4 & 7,5 & 4,7 & $2,00 \%$ \\
\hline INDÚSTRIA & & & & & & & & \\
\hline & Mato Grosso & 163 & 170 & 156,5 & 166,2 & 143,5 & 139 & \\
\hline Indústria geral & $\begin{array}{l}\text { Região } \\
\text { Metropolitana }\end{array}$ & 45,5 & 45,7 & 40,2 & 42 & 35,7 & 35,2 & $26,30 \%$ \\
\hline & Cuiabá & 26,5 & 28,5 & 21 & 24,7 & 21,5 & 20 & \\
\hline & Mato Grosso & 130,7 & 137 & 156,2 & 147 & 137,5 & 132,2 & $15,15 \%$ \\
\hline Construção & $\begin{array}{l}\text { Região } \\
\text { Metropolitana }\end{array}$ & 39,2 & 39,7 & 45,2 & 44,5 & 38,7 & 36 & $28,94 \%$ \\
\hline & Cuiabá & 24 & 24,5 & 31 & 30 & 26,2 & 23,2 & $18,90 \%$ \\
\hline TERCIÁRIO & & & & & & & & \\
\hline Comércio, & Mato Grosso & 293,7 & 318 & 331,2 & 313,5 & 304,2 & 308,7 & \\
\hline $\begin{array}{l}\text { reparação } \\
\text { veículos }\end{array}$ & $\begin{array}{l}\text { Região } \\
\text { Metropolitana }\end{array}$ & 99,5 & 103 & 99,7 & 98 & 92,5 & 89,2 & $31,12 \%$ \\
\hline $\begin{array}{l}\text { automotores } \\
\text { motocicletas }\end{array}$ & Cuiabá & 65,5 & 67,2 & 58,2 & 59,5 & 57,5 & 54,2 & $19,37 \%$ \\
\hline & Mato Grosso & 64,7 & 71,5 & 74,5 & 68,5 & 76 & 79 & \\
\hline armazenagem & $\begin{array}{l}\text { Região } \\
\text { Metropolitana }\end{array}$ & 18,7 & 22,7 & 21,2 & 21,5 & 21 & 22,5 & $29,38 \%$ \\
\hline & Cuiabá & 11,5 & 13,5 & 12,5 & 12,7 & 11,5 & 13,7 & $17,36 \%$ \\
\hline & Mato Grosso & 60,2 & 70,7 & 69 & 68 & 69,7 & 81 & \\
\hline $\begin{array}{l}\text { Alojamento } \\
\text { alimentação }\end{array}$ & $\begin{array}{l}\text { Região } \\
\text { Metropolitana }\end{array}$ & 20,7 & 25,5 & 22 & 24,2 & 24,2 & 27,2 & $34,35 \%$ \\
\hline & Cuiabá & 13,5 & 16,5 & 14,7 & 15,7 & 16,5 & 19,5 & $23,02 \%$ \\
\hline Informação, & Mato Grosso & 109,5 & 119 & 122,2 & 119,7 & 106,5 & 120,7 & \\
\hline $\begin{array}{l}\text { comunicação } \\
\text { atividades } \\
\text { financeiras, }\end{array}$ & $\begin{array}{l}\text { Região } \\
\text { Metropolitana }\end{array}$ & 50 & 53,2 & 52,2 & 49,7 & 45,7 & 53,5 & $43,62 \%$ \\
\hline $\begin{array}{l}\text { imobiliárias, } \\
\text { profissionais } \\
\text { administrativas }\end{array}$ & Cuiabá & 39 & 40,5 & 40,7 & 36,7 & 35,7 & 40,5 & $33,41 \%$ \\
\hline Administração & Mato Grosso & 232 & 227,7 & 234,2 & 229,2 & 240,7 & 257 & \\
\hline $\begin{array}{l}\text { pública, defesa, } \\
\text { seguridade social, } \\
\text { educação, saúde }\end{array}$ & $\begin{array}{l}\text { Região } \\
\text { Metropolitana }\end{array}$ & 84,7 & 81 & 81,7 & 75,7 & 81,2 & 93,2 & $35,01 \%$ \\
\hline $\begin{array}{l}\text { humana e serviços } \\
\text { sociais }\end{array}$ & Cuiabá & 65,7 & 62,7 & 65,2 & 58,5 & 62 & 67,2 & $26,83 \%$ \\
\hline & Mato Grosso & 53,7 & 61 & 63,7 & 60 & 58,2 & 56,7 & \\
\hline Outro serviço & $\begin{array}{l}\text { Região } \\
\text { Metropolitana }\end{array}$ & 19,7 & 22,5 & 23 & 22,2 & 20,5 & 20,2 & $36,25 \%$ \\
\hline & Cuiabá & 13,7 & 15,7 & 15,7 & 14,7 & 14 & 12,2 & $20,46 \%$ \\
\hline
\end{tabular}

Fonte: PNAD Contínua - Retrospectiva 2012-2017 - Médias Anuais - www.ibge.com.br, acesso: agosto de 2018.

Organizado pelo autor. 
Em contrapartida, o setor da indústria (geral), inter-relacionado ao setor da agropecuária, apresenta 26,30\% de trabalhadores empregados na Região Metropolitana e 15,15\% em Cuiabá. Ainda no segmento industrial, a atividade da construção civil concentra 28,94\% de pessoas empregadas na Região Metropolitana e 18,90\% em Cuiabá, números que são significativos. Já no setor terciário, nas atividades de comércio, reparação de veículos automotores e de motocicletas, a Região Metropolitana reúne 31,12\% de trabalhadores ocupados e Cuiabá, 19,37\%.

As atividades de transporte, armazenagem e correio na Região Metropolitana concentram 29,38\%, e Cuiabá, $17,36 \%$ de trabalhadores ocupados. Ainda no setor terciário, há destaque para a atividade de alojamento e alimentação: a Região Metropolitana concentra 34,35\% de pessoas ocupadas e Cuiabá 23,02\%. Sobressair a significativa importância da Região Metropolitana e de Cuiabá, que concentram 43,62\% e $33,41 \%$ pessoas ocupadas, respectivamente, nas atividades de informação, comunicação e atividades financeiras, imobiliárias, profissionais e administrativas, bem como nas atividades de administração pública, defesa, seguridade social, educação, saúde humana e serviços sociais, que concentram $36,25 \%$ de pessoas ocupadas na Região Metropolitana e 20,46\% em Cuiabá.

Esses dados são fundamentais para compreendermos, por um lado, a relação entre o crescimento econômico de Mato Grosso, especialmente da agropecuária, e a centralidade das atividades terciárias, principalmente da administração pública no sentido da concentração da decisão política e da gestão estatal da agropecuária; por outro, como a informação, a comunicação e especialmente as atividades financeiras e imobiliárias ganham relevo na concentração de pessoas ocupadas nessas atividades, revelando, em certo sentido, a aplicação do excedente produtivo agrário na cidade. Constata-se, na figura 9, que a taxa de trabalhadores desocupados é crescente no Brasil; no ano de 2012, a taxa era de 7,3\%, subindo drasticamente para 12,7\%, sem queda nos índices. Em Mato Grosso a situação não é diferente, tendo subido de 6,1\% em 2012 para 10,4\% em 2017. 
Figura 9 - Taxa de Desocupação 2012-2017 - Brasil e Região Centro-Oeste

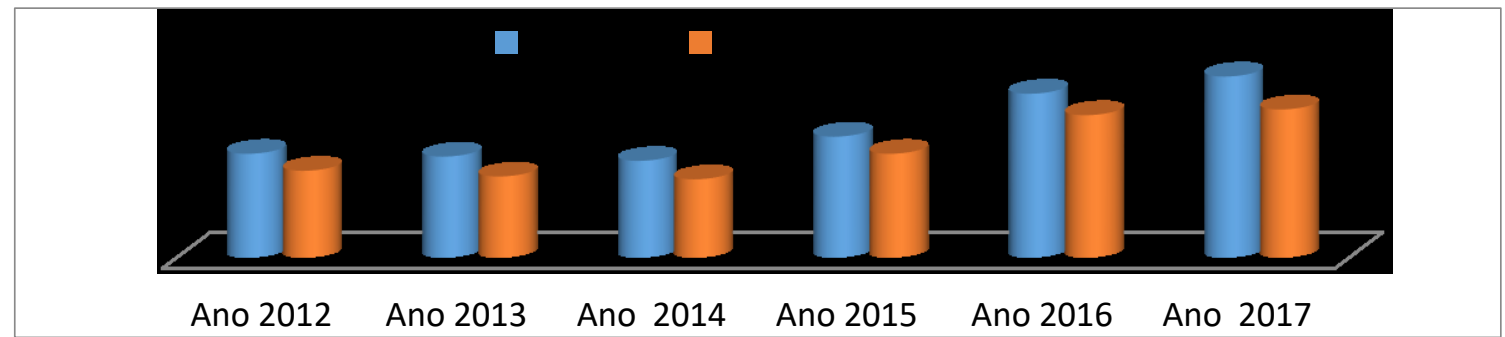

Fonte: PNAD Contínua - Retrospectiva 2012-2017 - Médias Anuais - www.ibge.com.br, acesso: agosto de 2018. Organizado pelo autor.

Podemos constatar na figura 10, a elevação das taxas de pessoas desocupadas em Mato Grosso: de 5,5\% em 2012 para 8,9\% em 2017. Na região Metropolitana, a taxa de trabalhadores desocupados foi ainda maior do que a estadual entre 2012 e 2015, chegando a 9,8\% em 2017. Em Cuiabá, a situação é ainda mais alarmante, passando de $5,6 \%$ para 11,5\%, mantendo-se ligeiramente maior do que as taxas estaduais e da Região Metropolitana.

Figura 10. Taxa de Desocupação 2012-2017 - Mato Grosso, Região Metropolitana e Cuiabá

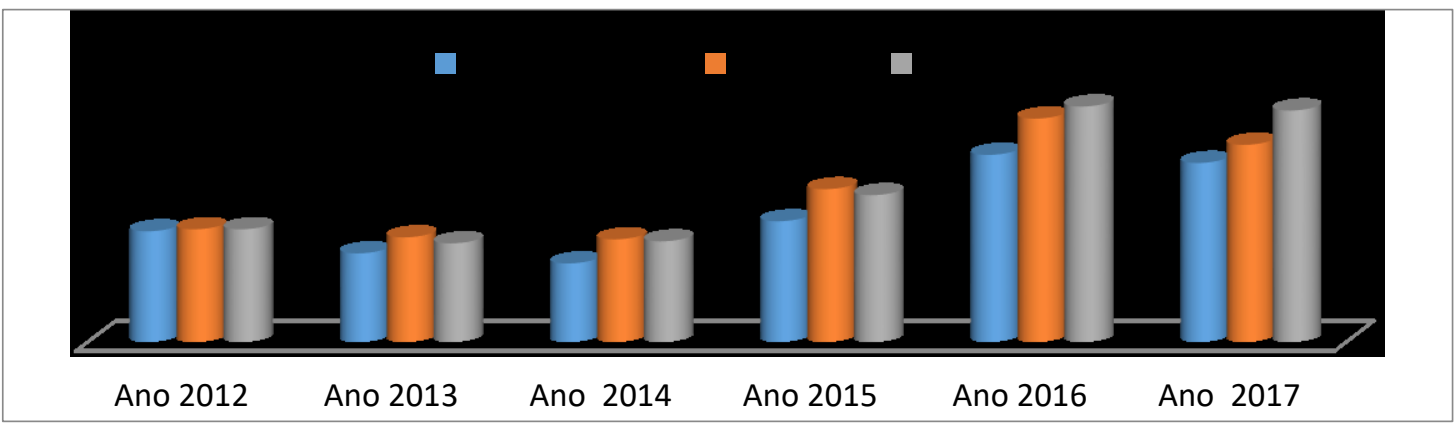

Fonte: PNAD Contínua - Retrospectiva 2012-2017 - Médias Anuais - www.ibge.com.br, acesso: agosto de 2018. Organizado pelo autor.

Isso significa que, embora haja maior concentração das atividades do setor da indústria e terciário, dinamizadas pelo crescimento econômico da agropecuária, paradoxalmente verifica-se, também, o aumento da taxa de trabalhadores desocupados na Região Metropolitana. Isso se dá em função da economia de Mato Grosso estar ligada ao mercado de exportação e ao mercado financeiro, que geram 
maior instabilidade na economia urbana e no aumento do desemprego em momentos de crises, sobretudo na Região Metropolitana, tal como consta no Plano Diretor de Desenvolvimento Integrado (PDDI) da Região Metropolitana do Vale do Rio Cuiabá (RMVRC):

No caso de Mato Grosso, o quadro internacional também é um fator de atenção, pois o estado tem suas finanças altamente ligadas ao mercado de exportações de commodities, especialmente soja, milho e carne bovina. [...] A recessão econômica que acabou por incidir na RMVRC nos últimos dois anos. Após momentos de pleno emprego - com taxas reduzidas de 4,40\%, em 2014 - viu o mercado de trabalho baixar a 12,90\% de desocupação entre as pessoas com 14 anos ou mais de idade, no primeiro semestre de 2016 (GOVERNO DO ESTADO DE MATO GROSSO, 2017, p. 27).

Os dados da taxa de trabalhadores desocupados revelam a contradição e o descolamento entre o crescimento econômico da agropecuária e o desenvolvimento social, considerando que, de 1989 até 2017, o saldo da Balança Comercial do Agronegócioxii foi crescente, sem oscilação negativa, mesmo em momentos de crises econômicas. Isso significa que os grandes produtores da agropecuária não têm sentido a crise como os trabalhadores e os empregadores urbanos. O aprofundamento da precariedade da vida desses trabalhadores pode ser constatado na figura 11, que revela os baixos salários e as oscilações do rendimento médio real habitual dos trabalhadores entre 2012 e 2017. Em 2012 e 2013, houve ínfimo aumento na renda média dos trabalhadores de Mato Grosso e do Brasil, elevação que continuou até 2014. Entretanto, em 2015 e 2016, houve oscilação para menores valores. Ao analisarmos o gráfico, constatamos também que a renda dos trabalhadores da Região Metropolitana e da cidade de Cuiabá é maior do que a média do estado e do Brasil, contudo, eles sofreram com constante desvalorização do trabalho, com sucessivas quedas no rendimento de 2012 a 2016. Vale destacar que, embora houvesse pequena elevação do rendimento em 2017, ela é inferior à renda de 2012. Destacamos, assim, a volatilidade no mercado de trabalho e no rendimentos médios dos trabalhadores, que 
apontam para a possível manutenção de lucro dos patrões que, no contexto geral, tiram proveito do enfraquecimento do movimento sindical e fazem bom uso das políticas de austeridade do governo, no sentido de desvalorizar os salários e a força de trabalho, conduzindo o número crescente de desempregados.

Figura 11. Rendimento Médio Real Habitual 2012-2017 - Brasil, Mato Grosso, Região Metropolitana e Cuiabá

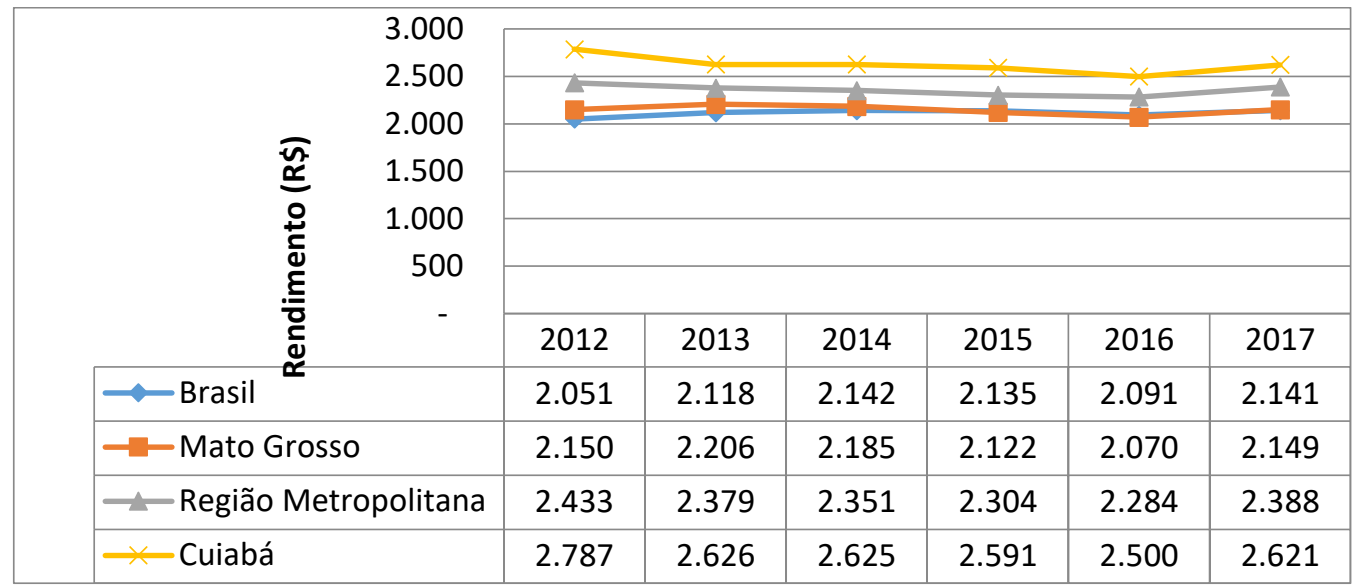

Fonte: PNAD Contínua - Retrospectiva 2012-2017 - Médias Anuais - www.ibge.com.br, acesso: agosto de 2018. Organizado pelo autor.

Constata-se, portanto, que o processo de crescimento econômico de Mato Grosso não tem promovido o desenvolvimento social, a melhora das condições de trabalho, melhores rendimentos, muito menos a redução das desigualdades. Os dados revelam o contrário o efetivo aumento da precarização da vida dos trabalhadores/moradores conduzindo o contraditório da centralidade econômica e social - a precarização da vida. São estes trabalhadores da Conurbação, que possuem esta média salarial, que contribuem para o ciclo do capital girar, seja por meio da venda da sua força de trabalho ou pelo consumo de mercadorias, realizadas para a manutenção de necessidades humanas, tal como aluguel (moradia), alimentação, vestuário, lazer, entre outros. É nesse sentido que as entrevistas e os questionários aplicados nos centros urbanos da Conurbação elucidam a contradição entre a formação de uma centralidade econômica e a precarização da centralidade lúdica e social. 


\section{AVANÇO DA FRONTEIRA - TRABALHADORES URBANOS - PRODUTORES DO CENTRO}

A produção do centro histórico de Várzea Grande está ligada ao processo de produção da agropecuária na cidade: “a partir de 1870, o povoado foi crescendo lentamente, pois a não ser o abate das reses para a manteação, a lavoura, a fabricação da lenha para venda em bruacas e em canoas e alguma indústria manual, tudo o mais se resumia num acanhado comércio varejista, sem nenhuma significação" (MONTEIRO, 1987, p. 22). Consequentemente Várzea Grande é historicamente dependente de Cuiabá: "tudo dependia de Cuiabá, onde a venda do exíguo produto era feita, completando-se, ato contínuo, a operação de compra e venda, com a aquisição das utilidades que então levavam para o povoado" (Idem, 1987, p. 22).

As primeiras vias de passagens de boiadeiros, bandeirantes paulistas e comerciantes definiram os traçados das principais avenidas da cidade, tal como a Avenida Senador Filinto Müller, onde foi construída a Igreja Nossa Senhora do Carmo, inaugurada em 1954 e reconstruída em 1970 (figura 12a), passando por várias reformas de ampliação e modernização até a configuração da Igreja no ano de 2014 (figura 12b). Essas duas imagens ilustram um lugar sagrado para os Católicos, lugar de fé de reunião, de encontro e sociabilidade, demarcando o processo da produção de centro e centralidades em Várzea Grande.

A Avenida Couto Magalhães é uma das principais ruas comerciais do centro de Várzea Grande, também está ligada ao processo de produção da agropecuária matogrossense, principalmente através de produção local e abastecimento da cidade de Cuiabá e região. Provavelmente por volta de 1940xiii (figura 13a), na até então Rua Couto Magalhães, instalavam-se os principais estabelecimentos comerciais que atendiam os moradores e trabalhadores daquele período. Em julho de 2014 (figura 13b), registramos a rua que se tornou a principal avenida da cidade, a "Couto Magalhães", onde se localizam diversos tipos de comércios, serviços e instituições financeiras, o que permite observar as funcionalidades do centro da cidade determinadas pelas necessidades da produção agropecuária. 
A determinação da vida dos trabalhadores, moradores e consumidores de modo geral está atrelada, de modo geral, à produção da agropecuária, inclusive na utilização, por parte dos trabalhadores, dos salários provenientes do trabalho e oferta de serviços dinamizados pelo setor agropecuário. Esses proventos são gastos no consumo de mercadorias ofertados pelos centros urbanos, as quais são necessárias principalmente para a reprodução de sua vida e, consequentemente, da força de trabalho.

Figura 12a. Igreja Nossa Senhora do Carmo em 1970, centro de Várzea Grande/MT

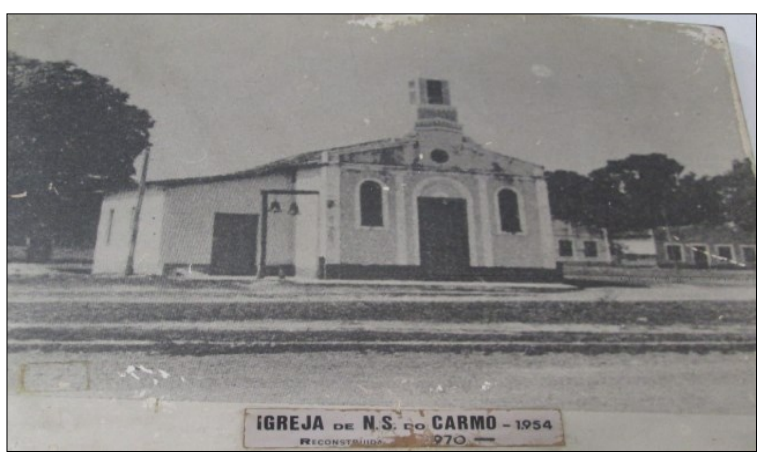

Fonte: Casa de Artes de Várzea Grande, 2014. Organizado pelo autor.

Figura 13a. Rua Couto Magalhães em 1940, Várzea Grande / MT

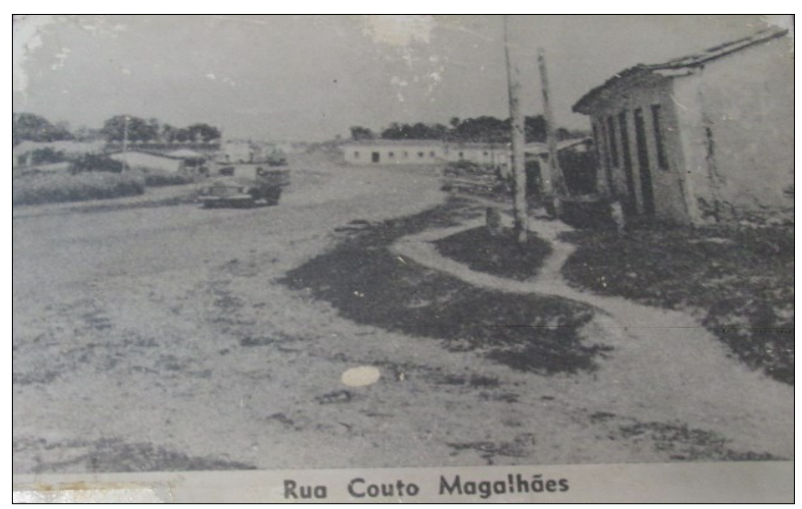

Fonte: Casa de Artes de Várzea Grande, 2014. Organizado pelo autor.
Figura 12b. Igreja Nossa Senhora do Carmo em 2014, centro de Várzea Grande/MT

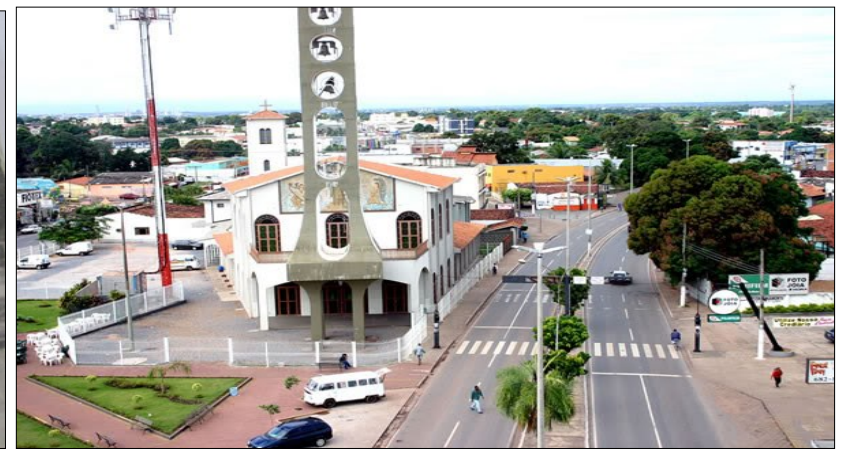

Fonte: http://www.skyscrapercity.com/showthread. php?t=962580> Acesso, mai. 2017. Organizado pelo autor.

Figura 13b. Av. Couto Magalhães em $2014-$ concentração de comércio, Várzea Grande/MT

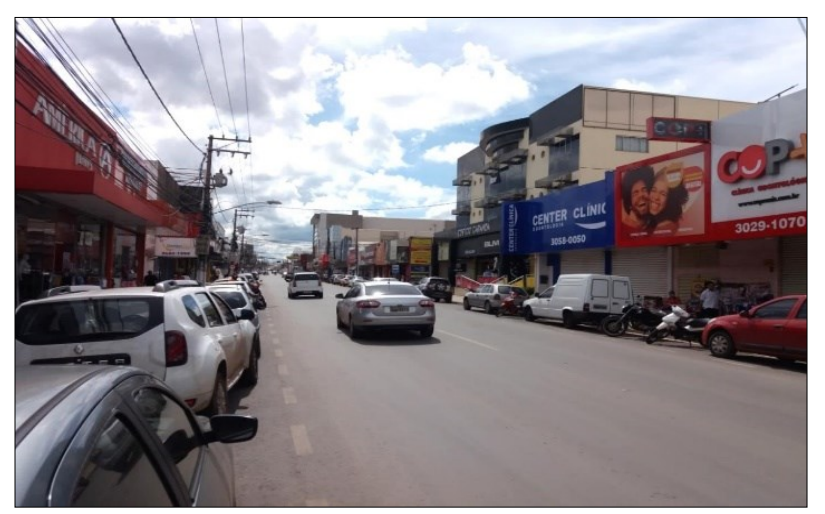

Fonte: acervo particular do autor.

A produção de centros remete à noção da produção do espaço urbano. Qual é, então, o sentido da cidade, da urbanidade e da centralidade social, quando o projeto maior é o avanço da fronteira agrícola e o crescimento econômico? Nesse sentido, a reestruturação produtiva capitalista promovida em Mato Grosso se realiza pela profunda transformação da vida das pessoas, submetendo-as a trabalhos degradantes, 
à expropriação de suas terras e, enfim, à acumulação por espoliação, processo que revela a dominação de classes e permite, consequentemente, a reprodução das relações sociais de produção. A colonização recente de Mato Grosso reporta-se ao processo de transformação da agricultura brasileira e das lógicas distintas de produção espacial. De um lado, o Estado, com os projetos capitalistas representados pelos grileiros latifundiários e empresários da agropecuária, sobretudo do Centro Sul do país, grupos econômicos nacionais e internacionais em busca da reprodução do capital; de outro, trabalhadores de várias localidades em busca da reprodução da vida, sejam eles colonos, posseiros, peões ou moradores de núcleos urbanos, inseridos de maneira precária e degradante no processo de reestruturação capitalista. Assim, a produção de centro na Conurbação, realizada pelos moradores destituídos de direitos sociais, subjugados pelos mandos e desmandos dos detentores da propriedade privada da terra e dos meios de produção, o revela o processo histórico da formação de uma centralidade concomitantemente social e periférica, no contexto de expansão da fronteira agrícola e da reprodução do capital.

O senhor Kiyoto, morador do centro de Várzea Grande, relata as contradições do processo de reprodução do capital em Mato Grosso por meio do avanço da fronteira agrícola. Por volta de 1955, ele e sua família ficaram entusiasmados com as propagandas de imigração promovida pelo governo brasileiro no exterior e vislumbraram a possibilidade de sair de um país devastado pelas grandes Guerras Mundiais e progredir financeiramente no Brasil. Kiyoto morou no Japão até aos 15 anos de idade e, por volta de 1960, veio para o Brasil com os seus familiares, o pai, a mãe, seis irmãos e três sobrinhos, totalizando onze pessoas. O Estado pretendia implantar colônias japonesas no norte/nordeste de Mato Grosso; caberia à família do senhor Kiyoto, juntamente com outros migrantes, concretizar o projeto de implantação da colônia Capem, localizada a cerca de 500 km de Cuiabá, perto das cidades de Nova Ubiratan e Feliz Natal. Mas eles encontraram dificuldades para permanecer no lugar, pois as promessas do Estado quanto a terra e progresso não se concretizavam ${ }^{\mathrm{xiv}}$. $\mathrm{O}$ entrevistado relata com detalhes as dificuldades de produzir alimentos, a falta de apoio efetivo do Estado e a precariedade geral da vida: 
Cada pessoa ganharia 10 alqueires de terras, na época a produção era plantação de seringa e pimenta do reino, mas o terreno não era bom para arroz, milho. Cada homem maior de 18 anos ganhava 10 alqueires de terras, começamos a derrubar a mata, fazer a plantação, casa para morar. Plantávamos arroz, se plantava 3 sacos de arroz e tirava só 6 , o terreno não era bom. Tinha que colocar cal para ficar bom. O que conseguíamos produzir era pimenta do reino (cerca de 3 anos), seringa também (mas demora 7 anos para produzir). Essa época era 1960 até 1972, depois saímos de lá. $\mathbf{O}$ governo não ajudou em nada, não houve ajuda para construir a casa, o terreno foi dado só de boca, não havia escritura e nada (kiyoto informação verbal - 2018) [grifos nosso].

O entrevistado também comenta a relação que ele e outros colonos do interior de Mato Grosso possuíam com o centro de Cuiabá, um lugar distante, onde, para se chegar, era necessária uma jornada penosa: "Quem tinha dinheiro, o caminhão ia uma vez ao ano para sair para a cidade, para Cuiabá, gastava cinco seis dias para chegar a Cuiabá" (kiyoto informação verbal - 2018) [grifos nosso]. Eles se dirigiam ao centro da cidade para vender alguns produtos e comprar o que era necessário, mas o regresso à colônia significava tentar a vida novamente reconhecendo a ausência do Estado, que não cumpria as suas promessas de progresso e modernidade feitas aos trabalhadores. Para Kiyoto, isso significou a memória da perda de seus entes queridos no trajeto esperançoso de melhores condições de vida:

Perdi meus pais lá, muitos perderam parentes, não havia nem ajuda para remédios do governo, do contrário não morreria tanta gente assim. Era difícil sair da colônia sem dinheiro, mas cinco famílias saíram de lá para Capim Branco, ganharam dinheiro e compraram caminhão, depois eles vieram buscar a nossa família para mudar para Capim Branco, fizemos acordos de meia (meeiros). Lá era terreno bom, deu plantação de arroz, feijão e milho, ficamos por dois anos no Capim Branco. Meu irmão ficou em Cuiabá, virou comerciante. Eu fui para Campo Grande, onde fiquei por dois anos, depois fui para Presidente Prudente, depois fui para a Capital (kiyoto informação verbal - 2018) [grifos nosso]. 
Durante a entrevista, Kiyoto silenciou e, com a voz embargada, disse: "sofremos de tudo, até sem roupas, saímos de lá sem nada", parte da sua família foi para Campo Grande /MS, e ele se mudou para São Paulo, onde morou e trabalhou com um amigo na produção de peças de caminhão; nas férias, trabalhava como costureiro e vendia os produtos no Brás para complementar a sua renda. Por volta de 1975, Kiyoto mudou-se para Cuiabá, onde o seu irmão havia conseguido se estabelecer financeiramente a partir do trabalho como comerciante no mercado municipal. Muitos trabalhadores mudaram-se para Cuiabá, partindo de vários estados brasileiros, ou foram recrutados nos núcleos urbanos das regiões produtivas, com promessas de receberem bons salários e benefícios. Entretanto, essas promessas não se concretizavam e os trabalhadores enfrentavam endividamento, usurpação da força de trabalho e constantes ameaças de morte.

O entrevistado de codinome Gustavo, de 65 anos, morador do bairro Glória, distante 5 minutos do centro de Várzea Grande, atualmente trabalha com prestação de serviços mecânicos na $\mathrm{Br}$ 364, mas trabalhou durante um período como peão, abrindo roçado no interior de Mato Grosso, participando do processo de recrutamento de trabalhadores dos núcleos urbanos para serviços braçais nas fazendas. Gustavo é natural de Nossa Senhora do Livramento, onde a sua família possuía por herança um sítio, em que plantavam para subsistência, até que começaram a ter dificuldades na pequena produção, pois a terra não produzia mais. Seu pai aceitou o convite de um amigo ribeirinho para ir morar em Várzea Grande.

Gustavo, juntamente com seu pai, sua mãe e seus irmãos, passaram a morar em uma casa cedida pelo amigo nas margens do Rio Cuiabá, na passagem da conceição, a partir de 1967, até conseguirem moradia própria. Por ali, eles trabalhavam como diaristas, limpando hortas e pastos na beira do rio, na região da Passagem da Conceição. Era um trabalho muito sofrido, lembra o entrevistado: "Ali estava difícil porque a gente não ganhava o suficiente, se trabalhava uma semana, não tinha trabalho na outra. E naquele tempo era uma dificuldade a cidade era quase que um sítio também" (Gustavo, informação verbal - 2018). Em função dessas dificuldades, a 
família de Gustavo mudou-se para um lugar chamado Parizinho (próximo ao Rio Pari que desagua no Rio Cuiabá), para uma terra cedida em que eles produziam arroz, feijão, café, cana, banana além de cortar lenhas para venda.

A maioria das pessoas daquela localidade cultivava cana-de-açúcar, faziam rapadura, pescavam, plantavam capim de praia para pastagem e dele faziam feixes; parte desses produtos era vendida no centro de Várzea Grande, e parte no Bairro Porto em Cuiabá (para realizar a travessia do rio, eles utilizavam balsas). Gustavo ainda relatou os tipos de aliciamento realizados pelos "Gatos", que contratavam trabalhadores da cidade para trabalhar na produção de pastagem. Ele descreveu as coações dos "capatazes"/ "Capitão do Mato", inclusive, um dos seus irmãos quase perdeu a vida, pois um capataz teria atirado em seu estômago. Gustavo e outros trabalhadores passaram a trabalhar em Nortelândia, nas terras da Empresa Camargo Corrêa, na produção de pasto, em condições de trabalho análogas à escravidão. Nas palavras do entrevistado:

Trabalhei na Camargo Corrêa, em Nortelândia, batendo pasto, não era assinada a carteira, era empreitada, convidavam as pessoas aqui para ir para lá. Muitas vezes você era enganado e tinha que aceitar, porque a lei lá era "federal", só que com nós não fizeram isso, porque nós nos unimos, éramos 11 pessoas que se uniram para trabalhar num leito só, num lote só, no mesmo roçado. Com a gente eles cumpriram o acordo, mas quem ia sozinho era enganado. A finalidade deles era fazer o camarada ir trabalhar e muitas vezes até descontar aquilo que você não pegou, então eles aproveitavam muito das pessoas. Mas não, já sabendo disso, nós já fomos daqui unidos. Havia muita malária, a pessoa estava no sol, coberto, se tremendo e o cara brigava com ele para colocar para trabalhar, e ainda tinha o famoso chefão que ficava prometendo matar a pessoa, dar tiro (não lembro a data, mas é por volta de 1970/80) (Gustavo, informação verbal - 2018).

O relato de Gustavo revela a profunda degradação da vida humana no processo de expansão da fronteira agrícola. Além disso, sua fala evidencia que a reestruturação produtiva acontece, sobretudo, através da dominação social e da força de repressão, 
do controle da força de trabalho e da acumulação por espoliação realizada pelos empresários agropecuários, conforme Oliveira (1997b):

As condições trágicas e eminentemente conflitivas às quais os peões do trecho estão sujeitos só se mantêm graças ao uso ostensivo da força armada das fazendas. De caráter intimidativo e repressivo, ultrapassa os limites das fazendas e invade os povoados: no trabalho ou no lazer, o manto do terror é onipresente no cotidiano do peão. Já os peões que se rebelam contra a imposição de seus mandantes, reagem fugindo, mas os jagunços iam a sua caçada. Nos anos de 70 e 80, várias agropecuárias de Mato Grosso, Pará e Maranhão conheceram essa violência contra os trabalhadores (1997b, p. 317).

Gustavo, Kiyoto e suas famílias foram submetidos às condições precárias de trabalho e de vida, bem como a deslocamentos forçados e direcionados para onde havia maior possibilidades de encontrar um trabalho rotativo, sem garantia e certeza de nada. As falas dos entrevistados revelam o movimento conflitivo da reestruturação produtiva racionalizada e da vida prática e social. Isso nos remete à lógica formal incorporada aos projetos racionalizados do Estado e dos capitalistas, sobre a qual Lefebvre afirma: a “ordem distante permanece abstrata enquanto não se incorpora na ordem próxima" (LEFEBVRE, 1973, p. 19), ou seja, há diversas práticas socioespaciais nas quais a reprodução das relações de produção invadem brutalmente as relações próximas, sobretudo com a profunda degradação da vida humana a que Gustavo e Kiyoto foram submetidos. Ao mesmo tempo, por meio das falas dos referidos entrevistados, percebe-se que a reestruturação produtiva não pode acontecer sem o consentimento social dos trabalhadores, que consciente ou inconscientemente são submetidos a diversas situações em meio à aflição na busca da reprodução da vida. As mudanças nas relações de trabalho, sobretudo nas fazendas e/ou nas colônias do interior de Mato Grosso, reportam-se ao processo de reestruturação produtiva e, como consequência, às transformações dos gestos corporais, do pensar, do viver, das relações sociais das pessoas e do trabalhador: 
Esta globalidade nova que (conscientemente ou não) tem como sentido e como fim a re-produção das relações de produção, mais ainda do que o lucro imediato ou o crescimento da produção, é acompanhada por uma modificação qualitativa profunda dessas relações. As relações de dominação que originalmente subtendem, reforçando-as, as relações de exploração, tornam-se essenciais, centrais (LEFEBVRE, 1973, p.34).

Nesse sentido, a reestruturação produtiva, além de gerar alterações nas relações de produção propriamente ditas (maquinários, trabalho, organização empresarial), modifica as relações sociais, da prática social, inclusive no processo de produção de uma centralidade periférica da Conurbação Cuiabá e Várzea Grande. Vale destacar que Kiyoto é morador do Centro de Várzea Grande, e Gustavo mora a cerca de 5 minutos do centro, próximo à Avenida Ulisses Pompeu de Campos, que faz divisa entre o centro da cidade com diversos bairros, dentre eles o 23 de Setembro, Jardim Panorama e Glória. Ambos, por meio das suas práticas sociais, construíram o centro, porém possuem com ele uma relação de estranhamento.

A noção de estranhamento é percebido também pela Joana, natural de Minas Gerais, onde sua família trabalhava na roça, plantava feijão, milho e arroz. Ela e sua família chegaram ao interior de Mato Grosso em 1966, mas não conseguiram se estabelecer por muito tempo, e mudaram-se para Várzea Grande em 1973. A entrevistada se lembra da configuração da cidade, do centro e do convívio social naquele período:

A cidade de Várzea Grande era pequena, as ruas principais eram calçadas, trabalhei como doméstica em Cuiabá, na Avenida Dom Bosco, depois trabalhei para a família Nadaf. No centro, a Igreja era pequena, só tinha o banco Bamerindus, tinha algumas casas de comércios, armazéns, mas não eram muitos. la à Igreja, passeava pela praça, conversava com os amigos, tinha uma feira ali perto, o único lugar para encontrar com os amigos era por ali, na praça, na feira, tinha também o clube dos operários onde o pessoal se encontrava, onde o pessoal fazia carnaval lá dentro (Joana, informação verbal - 2018). 
É possível notar, na fala da entrevistada, que não havia lugares para convívio social em Várzea Grande, que era caracterizada por pouca urbanização, delimitação da área central, marcada pelos momentos de encontro para compra na feira. Joana relata que o Bairro Glória tinha poucos moradores por volta de 1975, que foram abrindo picadão para fazer as ruas sem esgoto e sem asfalto. Não havia água nem energia elétrica para realizar serviços domésticos, então ela e outros moradores retiravam água de poços $^{\mathrm{xV}}$ construídos por eles próprios. Quando a água estava enlodada e mal cheirosa, em péssimas condições para uso, eles caminhavam até os rios para lavar roupas e buscar quanto fosse possível para consumo doméstico. As determinações da relação centro-periferia evidenciam-se na seguinte fala de Joana: “O posto de saúde também era longe, ficava no centro, não tinha rua aqui, era só picadão, não tinha ônibus, andava a pé. Aqui ainda continua quase a mesma coisa, falta asfalto, não temos praça pública" (Joana, informação verbal - 2018). Joana disse ainda que quase não havia reuniões comunitárias no bairro. Às vezes, segundo ela, o líder comunitário se mobilizava para levar as cooperativas para vender verduras com preços mais baixos para os moradores, e também havia ações sociais de doação de cobertores, roupas de frio e ticket de leite, além de oferta de cursos de datilografia, manicure, tricô e cortes de cabelo para o povo trabalhar em casa.

Rúbia atualmente possui um pequeno ponto comercial no Cristo Rei que está alugado, é cuidadora de idosos e trabalha no Bairro Porto em Cuiabá. Ela tem pouca relação com o centro de Várzea Grande, pois, na maioria das vezes, dirige-se ao centro do Cristo rei e de Cuiabá para ir ao mercado, a lojas e para resolver assuntos burocráticos. A moradora critica a precariedade da vida na cidade, a ausência de espaço público social e de lazer: “Aqui em Várzea Grande não tem lazer nenhum. Uma praça boa, uma praça cultural, um teatro, essas coisas não tem" (Rúbia, informação verbal - 2018). A entrevistada relata que muitos moradores se dirigem para Cuiabá em busca de lazer: "Geralmente vamos ao Shopping, na Arena Pantanal, na Orla do Porto. Se você vai lá em Cuiabá está lotada de gente, tem moradores de Várzea Grande lá. (Rúbia, informação verbal - 2018). Ela relata ainda que há representante comunitário 
que convoca os moradores para as reuniões, que ocorrem geralmente aos domingos. Ele e a comunidade organizam protestos para reivindicar melhorias no bairro, tal como a construção de posto de saúde, a manutenção dos asfaltos e esgotos, em suma, coisas mínimas, como diz Rubia. Ela faz migrações pendulares entre Cuiabá e Várzea Grande, e relata dificuldades de mobilidade para realizar os deslocamentos diários de transporte coletivo entre as duas cidades, pois o ônibus que faz a linha do bairro Santa Clara demora mais de 2 horas para passar.

Voltemos ao relato de Kyoto. Um conhecido ajudou-o a abrir um bar, localizado no Bairro Porto, perto da Avenida XV de novembro; depois, ele abriu uma lanchonete e, em seguida, um restaurante. Por causa da construção do Centro Político Administrativo, por volta de 1983, havia um fluxo maior de trabalhadores naquela região, e Kiyoto vendia marmitas para essas pessoas. Após certo tempo, o entrevistado adquiriu um terreno, construiu um barracão e fez dele um estacionamento, posteriormente alugado para a Caixa Econômica Federal. Por volta de 1990, Kiyoto voltou para o Japão, morou lá por 20 anos e retornou para o Brasil. Desde então, ele mora no centro de Várzea Grande. Kiyoto não fez comentários negativos sobre o centro de Várzea Grande, mesmo não tendo opções de socialização, à exceção do Centro Cultural Nipo Mato-grossense, localizado perto da sua residência, lugar que ele frequenta todos os finais de semana para encontrar com os amigos e jogar Beisebol. Segundo ele, o centro está ótimo, e Várzea Grande não é mais uma cidade de interior.

Voltemos, também, ao relato de Gustavo. O entrevistado afirmou que parte da Avenida Filinto Mulher, localizada no centro da cidade de Várzea Grande, era calçada, mas a maioria das ruas, inclusive do centro, era de terra. Havia, ali, uma das poucas Instituições Bancárias no centro, o Banco Bradesco, além de um posto de gasolina. Essa área era repleta de matas com árvores grandes, lembra o entrevistado. Em 1971, Gustavo mudou-se com a família para o Loteamento Glória, comercializado pela imobiliária Glória, no qual deu entrada com a renda de trabalhos temporários, inclusive do trabalho em olaria (localizado depois do Posto Gil). 
Na época, o bairro, localizado a cinco minutos do centro da cidade, não possuía energia elétrica nem asfalto, e as casas que ali estavam haviam sido autoconstruídas. De 1972 a 1975, Gustavo trabalhou na fabricação de tijolos nas imediações da estrada da Guarita, enquanto o seu pai passou a trabalhar como pedreiro na construção de casas do Centro Político Administrativo, especificamente no CPA I, II e III. A partir da década de 1980, Gustavo trabalhou por doze anos como mecânico, na altura do Zero quilômetro, sem carteira assinada. Fazia reparos nos carros e carretas que trafegavam da região sudeste, passavam por Várzea Grande e adentravam as cidades do interior de Mato Grosso.

Hoje, o entrevistado trabalha na $\mathrm{Br} 364$ em uma oficina mecânica de porte grande, que atende os caminhoneiros que transportam a produção de commodities do interior de Mato Grosso, tais como Nova Xavantina, Lucas do Rio Verde, Sinop, Alta Flores, Sapezal, e de vários estado do Brasil, tal como Rio Grande do Sul, do Paraná, Santa Catarina, Goiás. Durante o ano de 2016, com o discurso da crise, o patrão de Gustavo queria reduzir as despesas com funcionários, propondo redução de salários, com justificativa de evitar o desemprego. Nesse processo, o sindicato foi chamado para intermediar as negociações com o patrão. A proposta inicial era criar contratos de 50\% de comissão, mas sem salário fixo, sem direito às férias ou com apenas $15 \%$ de comissão com direito a férias e um salário base de 1.200,00 reais. Com a atuação do sindicato, os trabalhadores conseguiram manter o salário base e aumentar a comissão para $20 \%$, mantendo os direitos trabalhistas.

Essas tensões entre patrão e trabalhadores remetem à reestruturação do trabalho, marcada pela crise econômica e desvalorização da força de trabalho (desemprego), bem como pelo enfraquecimento dos sindicatos trabalhistas (fragmentação da classe trabalhadora e da luta), constituindo momento propício para os capitalistas imporem regimes e contratos de trabalho mais flexíveis, o que explica o aumento do número de trabalhadores em tempo parcial, temporário ou subcontratados. Ao mesmo tempo, uma parcela de "trabalhadores estabilizados" na empresa conta com maior possibilidade de promoção, reciclagem, pensão, seguros, 
desde que tenha disposição de "ser flexível, adaptável e, se necessário, geograficamente móvel" (HAVEY, 2012, p. 144).

\section{CONSIDERAÇÕES FINAIS}

A reestruturação do capital tem significado a busca insaciável de novas áreas de reprodução do valor de troca, na qual o avanço da fronteira agrícola na região CentroOeste, a partir de 1970, cumpre o seu papel da forma mais perversa e pseudomoderna possível, pela recomposição das dominações de classe, perpetuação da propriedade privada da terra, latifúndios e expropriação dos trabalhadores. A abertura de novas áreas para reprodução do capital mundial potencializou o crescimento econômico da agropecuária mato-grossense, no desenvolvimento da agroindústria, sobretudo no fortalecimento do agronegócio a partir de 1990 pela produção de commodities altamente vinculada ao mercado financeiro global, contribuindo para a superação dos momentos de estagnação e desvalorização do capital manifestado nos momentos de superacumulação e crises. Desse modo, contata-se a crescente centralidade econômica na Conurbação revelada pelo número de: armazéns, graneleiros, indústria de transformação, empresas de transporte, armazenagem, correio, empresas de alojamento, alimentação, agências bancárias e operações de crédito, evidenciando a mobilidade de operações creditícias e financeiras no âmbito da produção da agropecuária moderna e de outras atividades econômicas a ela correlacionadas.

A centralidade urbana e econômica predominante advém principalmente dos setores de comércio e serviços. Constatamos que embora haja maior concentração das atividades do setor da indústria e terciário, dinamizadas pelo crescimento econômico da agropecuária, paradoxalmente verifica-se, também, o aumento da taxa de trabalhadores desocupados na Região Metropolitana. Isso se dá em função da economia de Mato Grosso estar ligada ao mercado de exportação e ao mercado financeiro, que geram maior instabilidade na economia urbana e no aumento do 
desemprego em momentos de crises. Além disso, destaca-se assim, a volatilidade do mercado de trabalho e dos rendimentos médios dos trabalhadores. Sendo assim, o crescimento econômico de Mato Grosso não tem promovido o desenvolvimento social, a melhora das condições de trabalho, melhores rendimentos, muito menos a redução das desigualdades. Os dados revelam o contrário o efetivo aumento da precarização da vida dos trabalhadores/moradores conduzindo o contraditório da centralidade econômica e social - a precarização da vida.

A partir das entrevistas, verifica-se que os trabalhadores urbanos contemporâneos não são mais formados por operários fabris como outrora. Eles compõem grupos diferentes, pois são diversos em muitos aspectos, múltiplos em suas aspirações, mas têm em comum a precariedade no trabalho. Ao mesmo tempo, no processo de autoconstrução e urbanização dos bairros, há uma noção de construção coletiva da cidade e de urgência de conquista de direitos sociais, que, mesmo que reivindicados de modo pontual e fragmentado, potencializam a sociabilidade, o diálogo e a perspectiva de luta pelo direito às condições materiais de reprodução da vida, à cidade e à centralidade.

A prática da centralidade social vivida na Conurbação revela a totalidade social marcada pelo desenvolvimento desigual, revelando que o sistema capitalista se sustenta pela constante espoliação, sobretudo das camadas populares, tornando a prática social cindida, com novos conteúdos da centralidade social cada vez mais dando lugar a uma centralidade econômica, sucumbindo e contrapondo-se aos usos sociais e à apropriação plena da centralidade social. O mundo social que identificamos na Conurbação está sendo selvagemente reestruturado, e cabe à apropriação social da centralidade criar estratégias espaciais capazes de questionar a reprodução da vida.

\section{REFERÊNCIAS}

CARLOS, Ana Fani Alessandri. A condição espacial. São Paulo: Contexto, 2011. 
GARBELINE, Camila Balista. Estudo dos vetores e expansão e análise de viabilidade do Distrito Industrial de Cuiabá - MT, 2014. Dissertação (mestrado) - Universidade Federal de Mato Grosso, Instituto de Ciências Humanas e Sociais, Pós-Graduação em Geografia, 2014.

GOVERNO DO ESTADO DE MATO GROSSO. Plano Diretor de Desenvolvimento Integrado (PDDI) da Região Metropolitana do Vale do Rio Cuiabá (RMVRC) Diagnóstico consolidado. Produto 1b/ Relatório 1. Versão Completa. Cuiabá, 2017. Disponível em: http://www.pddivrc.ibam.org.br/wpcontent/uploads/2017/12/p1b_diagnostico-1.pdf Acesso, novembro de 2018.

HARVEY, David. Os limites do capital. Tradução de Magda Lopes [1 ${ }^{\text {a }}$ ed.] São Paulo: Boitempo, 2013.

HARVEY, David. Condição pós-moderna: Uma Pesquisa Sobre as Origens da Mudança Cultural. Edições Loyola, São Paulo, 2012.

HARVEY, David. Re-produção das relações de produção. Publicações Escorpião. Cadernos: O homem e a sociedade. Porto, 1973.

LEFEBVRE, Henri. A produção do espaço. Trad. Doralice Barros Pereira e Sérgio Martins (do original: La production de l'espace. 4e éd. Paris: Éditions Anthropos, 2000). Primeira versão: início - fev.2006.

MONTEIRO, Ubaldo. Várzea Grande: Passado e presente confrontos, 1867 - 1987. Cuiabá, Ed Policromos. 1987.

MÜLLER, Geraldo. Complexo agroindustrial e modernização agrária. São Paulo: HUCITEC, 1989.

SEDEC, Secretaria de Estado de Desenvolvimento Econômico (). DISTRITO INTEGRADO INDUSTRIAL E COMERCIAL DE CUIABÁ. Disponível em: http://www.sedec.mt.gov.br/-/517643-distrito-industrial?ciclo= Acesso: janeiro de 2019.

SPOSITO, Maria Encarnação Beltrão. Segregação socioespacial e centralidade urbana. In: VASCONCELOS, CORREA, PINTAUDI (Org.). A cidade contemporânea: segregação espacial. São Paulo: Contexto, 2013.

\footnotetext{
i Esclarece-se que as palavra Estado (inicial maiúscula) e estado (inicial minúscula) se tratam de conceitos diferentes. A palavra Estado para se referir ao conjunto das INSTITUIÇÕES que compõem a administração dessa nação. E estado para referir à divisão territorial brasileira.

ii Disponível em:< http://www.dados.mt.gov.br/publicacoes/anuarios/> Acesso janeiro de 2019.
} 
iii No item 2.2 da seguinte tese: constata-se a análise do processo de espraiamento do tecido urbano e formação da Conurbação Cuiabá-Várzea (Será inserido após a aprovação do artigo, pois identificaria o autor).

iv Município é o espaço territorial político dentro de um estado ou unidade federativa, é o espaço administrado por uma prefeitura, engloba-se a sua zona rural e a zona urbanizada.

v Para mais informações acessar tabela 2: Valor Adicionado Bruto por atividades econômicas em Mato Grosso, variação nominal e variação real - 2002 a 2016. Disponível em:

<http://www.seplan.mt.gov.br/documents/363424/11245058/Cen\%C3\%A1 rio+Socioecon\%C3\%B4mico+v+1. 0.01+conclu\%C3\%ADdo+20190329.pdf/05c8f4d6-4bbb-ff02-c122-e6518a6ae1a8 $>$. Acesso, julho de 2020.

vi Esclarecemos que utilizamos os dados das empresas internacionais e nacionais no ramo da agropecuária a partir dos quadros e tabelas organizadas por Muller, (1989), em seguida pesquisamos quais dessas empresas possuem atuação na Conurbação.

vii GAZETA DIGITAL. Monsanto inaugura centro de distribuição de sementes em Cuiabá. Fonte: $<$ http://www.gazetadigital.com.br/suplementos/terra-e-criacao/monsanto-inaugura-centro-de-distribuicao-desementes-em-cuiaba/136073> Acesso: jan. 2019.

viii No item capítulo 4 da seguinte tese:

encontra-se mais detalhes referente as indústrias, armazenagens, concentração do financiamento da produção agropecuária na Conurbação, e de modo amplo, as relações entre o agronegócio e as funcionalidades urbanas da Conurbação Cuiabá-Várzea Grande. (Será inserido após a aprovação do artigo, pois identificaria o autor).

ix Na tese: analisa-se os planos estratégicos do governo estadual, os discursos e as práticas para o fortalecimento da Conurbação como centro financeiro altamente dinâmico e moderno, através da construção de novas centralidades turísticas, científicas e tecnológicas. (Será inserido após a aprovação do artigo, pois identificaria o autor).

x A média acumulada se refere à da soma dos dados de 2012 a 2017 e suas respectivas porcentagens.

xi Ver primeiro capítulo da seguinte tese: constata-se a análise do processo de espraiamento do tecido urbano, formação da Conurbação e comparativo da renúncia de receita com a irrisória geração de empregos (Será inserido após a aprovação do artigo, pois identificaria o autor).

xii Ver análise da Balança Comercial Brasileira no primeiro capítulo da seguinte tese: (será inserido após a aprovação do artigo, pois identificaria o autor).

xiii Não há informação da data do registro fotográfico na figura 10; nem mesmo os servidores da Casa de Artes de Várzea Grande souberam informá-la.

xiv Deve-se problematizar o fato de que muitos grileiros/empresários/políticos apossaram-se ilegalmente de terras e, hoje, são grandes produtores. Ver mais em: SILVA, Ligia Osório. Terras devolutas e latifúndio. Campinas: Editora da Unicamp, 2008, $2^{\mathrm{a}}$ edição.

Xv A falta de água tratada constitui-se como um problema histórico na cidade, tal como demonstram também as reportagens: "Parece mentira. Mas a periferia passa sede", Jornal "O CORREIO", ano III, n 105, Várzea Grande, 26/01/1986. Protestos dos moradores do bairro Jardins dos Estados, mais de três meses sem água. Reportagem: "Santa Terezinha, um bairro sem água, luz ou escola", Jornal "O CORREIO", Várzea Grande 25 a 31/05/1986. Jornal Dados acessados no Arquivo Público de Mato Grosso. 